
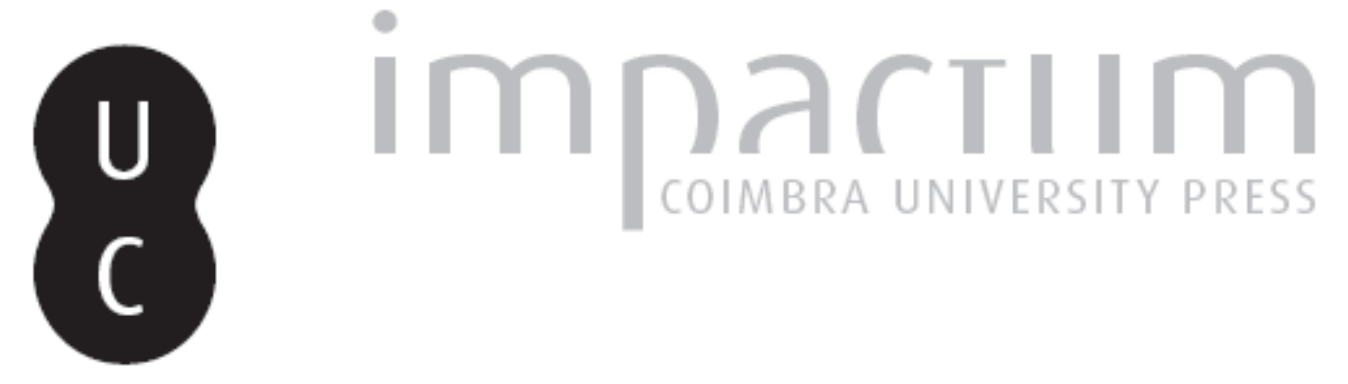

Teodorico de Freiberg: tratado sobre a origem das coisas categoriais $\left(2^{\mathrm{a}}\right.$ parte)

Autor(es): $\quad$ Augusto, Luís M., trad.

Publicado por: Faculdade de Letras da Universidade de Coimbra, Instituto de Estudos

URL

persistente: URI:http://hdl.handle.net/10316.2/29470

DOI: $\quad$ DOl:http://dx.doi.org/10.14195/0872-0851_41_10

Accessed : $\quad$ 26-Apr-2023 16:04:43

A navegação consulta e descarregamento dos títulos inseridos nas Bibliotecas Digitais UC Digitalis, UC Pombalina e UC Impactum, pressupõem a aceitação plena e sem reservas dos Termos e Condições de Uso destas Bibliotecas Digitais, disponíveis em https://digitalis.uc.pt/pt-pt/termos.

Conforme exposto nos referidos Termos e Condições de Uso, o descarregamento de títulos de acesso restrito requer uma licença válida de autorização devendo o utilizador aceder ao(s) documento(s) a partir de um endereço de IP da instituição detentora da supramencionada licença.

Ao utilizador é apenas permitido o descarregamento para uso pessoal, pelo que o emprego do(s) título(s) descarregado(s) para outro fim, designadamente comercial, carece de autorização do respetivo autor ou editor da obra.

Na medida em que todas as obras da UC Digitalis se encontram protegidas pelo Código do Direito de Autor e Direitos Conexos e demais legislação aplicável, toda a cópia, parcial ou total, deste documento, nos casos em que é legalmente admitida, deverá conter ou fazer-se acompanhar por este aviso. 


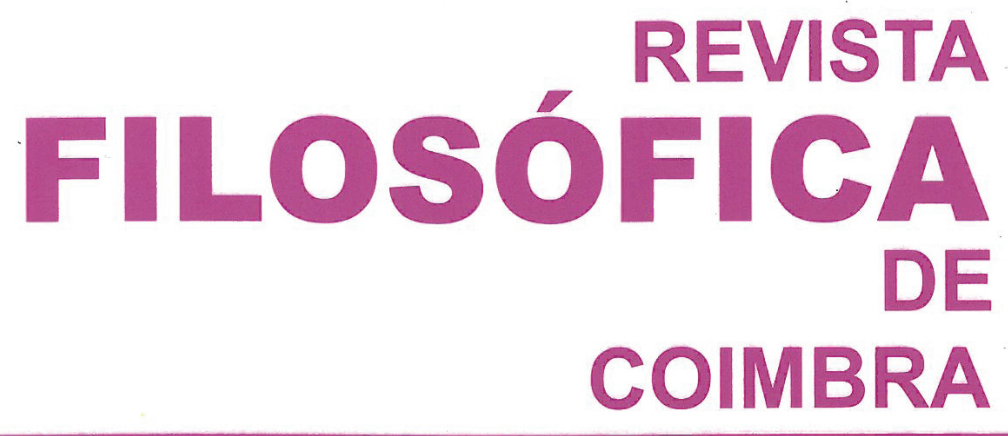

vol. 21 - número 41 - março 2012

vol. 21 - número 41 - março 2012

Fundação Eng. António de Almeida

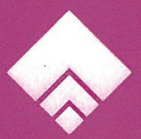




\section{TEODORICO DE FREIBERG TRATADO SOBRE A ORIGEM DAS COISAS CATEGORIAIS}

LUÍS M. AUGUSTO*

\section{Introdução ${ }^{1}$}

\section{Introdução Analítica às Diferentes Partes do Tratado}

\subsection{Capítulo 3}

Teodorico propõe-se agora abordar a questão metafísica $(\mathrm{cf} . \mathbf{3}, \mathbf{1})$ da pertença à (ou exclusão da) classe de género: o que é necessário para que um ente pertença à classe de género, ou seja, para que ele constitua ou pertença a uma categoria? Três aspectos têm de se encontrar simultaneamente presentes num ente para que em si e originariamente ele possa constituir ou pertencer a uma categoria (cf. 3, 2-12):

1. É uma coisa natural ou importa uma coisa natural; os entes que importam uma coisa natural fazem-no

1.1. no modo daquilo que subsiste em si mesmo, ou seja, o modo da substância;

1.2. ou no modo daquilo que determina ou modifica formalmente, activa ou passivamente, uma substância em termos de uma operação natural. Tal pode ser de três modos:

1.2.1. estas determinações são certas naturezas e são princípios de tais operações ou movimentos em si quanto àquilo que principalmente se significa pelo nome: quantidades e qualidades naturais das coisas;

* Instituto de Filosofia, Universidade do Porto.

${ }^{1}$ Publica-se agora a tradução dos Capítulos 3 e 4 do texto da autoria de Teodorico de Freiberg Tratado sobre a Origem das Coisas Categoriais, dando-se seguimento à publicação já iniciada: vd. Revista Filosófica de Coimbra 20 (2011) 507- 552. Para a Introdução geral ao texto e à sua temática, vd. o mesmo volume pp. 507-24. 
1.2.2. alguns entes comportam-se de um modo como que causal em relação aos movimentos mencionados dos entes ou aos seus princípios e são criados a partir destes por uma razão agente: relações; ainda algumas quantidades e qualidades;

1.2.3. entes que em relação aos ditos movimentos são ou operações naturais das coisas, ou princípios delas em termos de determinações naturais destas como que num modo circunstancial: as restantes seis categorias, a lembrar, lugar, tempo, posição, estado (ou posse), aç̧ão e paixão.

2. É um ente completo uma vez alcançada a sua perfeição, a qual lhe é própria segundo a sua própria noção e o modo da sua essência, nomeadamente ao ter a sua própria espécie.

3. Participa da noção comum de um género, a qual pode ser tomada de dois modos:

3.1. de acordo com a natureza de uma coisa tomada em si e absolutamente (perspectiva metafísica): trata-se aqui do princípio de um género, a forma, a qual, porém, tem de conter em si uma intenção correspondente à unidade da matéria, ou do princípio material ${ }^{2}$;

3.2. em termos de uma analogia (perspectiva lógica): a proporcionalidade, ou relação de igualdade entre duas coisas (por exemplo, diz-se tanto das coisas corpóreas como das incorpóreas que são substâncias pelo modo de substar que se encontra proporcionalmente em ambas).

Duas coisas são de realçar no que diz respeito a esta listagem: em primeiro lugar, enquanto as primeiras quatro categorias (substância, quantidade, qualidade e relação) são consideradas como o fruto de uma operação natural, as restantes seis (cf. 1.2.3. acima) resultam de uma operação do intelecto (cf. 3, 7); em segundo lugar, e isto com respeito ao ponto 3 . da listagem em questão, o número de dez das categorias aristotélicas não é estabelecido por uma consideração verdadeiramente metafísica (cf. 3.1.), mas somente por uma consideração lógica (cf. 3.2.) que, porém, não parece diferir de meros "modos de falar" (cf. 3, 12). Com efeito, há entes que não pertencem a nenhum género, e há ainda outros que só o fazem por redução (per reductionem), o que, porém, implica uma natureza imperfeita ou incompleta.

Tendo em conta este cenário, Teodorico indica então os entes que não constituem ou pertencem a um género de categoria:

- por 1., as coisas de razão ou coisas de intenção segunda (não importam nenhuma noção de ente; cf. 3, 14), os pós-predicamentos (não importam nenhuma natureza ou determinação natural em relação a uma substância, senão por acidente ou ainda segundo o modo de falar prevalecente ou pela probabilidade; cf. $3,15)$ e as propriedades dos entes (embora pertençam ao mesmo género das coisas-sujeito; cf. 3, 16);

${ }^{2}$ Isto implica que entes absolutamente simples não pertencem a nenhum género de categoria. 
- por 2., os princípios intrínsecos de um género (cf. 3,17$)$ e certos entes incompletos (ex.: os embriões; cf. 3, 20); os primeiros levantam o problema dos graus de mais e menos (cf. 3, 18-19), e os segundos a questão "bicuda" da relação entre a potência e o acto. Com relação ao primeiro problema, visto que se pode objectar que há entes que pertencem a um género próprio e específico apesar de apresentarem graus (por exemplo, de brancura ou de calor), Teodorico distingue dois modos segundo os quais os entes recebem graus de mais e menos, um em que os entes recebem graus de mais e menos de acordo com a progressão para o acto final de acordo com o qual pertencem de facto a um género próprio, e outro em que esta recepção se dá de acordo com a intensificação ou diminuição de uma espécie já estabelecida: neste último caso, alguns entes podem de facto pertencer a um género em termos do seu acto específico; no primeiro caso, tal não se verifica. No que diz respeito ao segundo ponto, como nos diz Teodorico, "dado que nos entes geráveis e corruptíveis tudo é em potência tudo, ainda que num grau diferente de maior ou menor análoga potência, parece que os entes geráveis e corruptíveis não pertencem a géneros e espécies determinados e que cada um pode pertencer a um género qualquer" $(\mathbf{3}, \mathbf{2 1})$. Teodorico analisa esta problemática numa longa discussão, sendo que a conclusão principal é que para que um ente em potência pertença ao mesmo género do ente em acto em relação ao qual ele é em potência é necessária a unidade da potência ao acto por um mesmo agente determinado que leva esse ente da potência ao acto (cf. 3, 29). Este é o caso dos embriões, na medida em que neste estado apresentam já a unidade da potência ao acto pela qual, e por um mesmo agente determinado, serão "levados" ao acto final; tal não se verifica noutros casos em que se pode falar de potência e acto, como, por exemplo, no caso do alimento, que é em potência o sangue de quem dele se nutre (falta aqui a unidade da potência ao acto devido à ausência da unidade nos diferentes agentes; cf. 3, 28), ou no caso da madeira que é em potência carvão (aqui o agente - o fogo - é comum ou universal, pelo que falta a unidade de um mesmo agente determinado; cf. 3, 27); o caso "ambíguo" dos instrumentos da natureza (ex.: o esperma) é elucidado em 3, 30. Terminada esta discussão, segue-se-lhe a abordagem de uma nova questão não menos problemática, a dos entes privados (cf. 3, 31-5): o que parece decidir esta questão é o ente privado (ex.: o animal morto) tomado em si ou em relação ao ente do qual ele é a privação; por exemplo, se se toma um animal morto em si mesmo, então ele não pertence ao mesmo género do animal que era enquanto vivo (cf. $\mathbf{3}, \mathbf{3 1}$ ); se porém se considera o animal morto como uma privação do animal vivo, então pertencem ambos ao mesmo género (cf. 3, 33). Esta discussão termina com uma proposição interessante relativamente aos acidentes, segundo a qual tudo aquilo que é por acidente é redutível àquilo que é em si, seja este a forma do ente formado, o sujeito comum, ou até mesmo a própria privação, a qual dá azo aos remates finais com relação a esta questão (cf. 3, 34-5).

- por 3., os entes simples ou inteligências (não partilham de nenhum princípio natural; ver o ponto 3.1. acima; cf. $\mathbf{3}, \mathbf{3 7}$ ); especificamente em relação àquilo que os entes têm de ter em comum para pertencerem a um mesmo género, exclui-se também o princípio primeiro de todos os entes, a natureza (cf. 3, 32), porque como princípio e causa de toda a ordem da natureza é necessário que se encontre fora dessa mesma ordem (cf. 3, 36). 


\subsection{Capítulo 4}

Teodorico aborda agora as questões eminentemente metafísicas da distinção entre ente e não-ente e da unidade e ordem das formas, a segunda questão sendo subordinada em relação à primeira. $\mathrm{O}$ objectivo central deste capítulo é a defesa da unidade da forma substancial contra os Franciscanos e contra Henrique de Gandavo em particular, também ele discípulo de Alberto Magno: é de acordo com a forma una que um ente é classificado num género próprio.

Segundo Teodorico, em primeiro lugar o ente difere do não-ente ou do nada pelo seu acto completo, e isto quer se considere o ente em termos das suas causas, isto é, no que respeita à geração $(\mathbf{4}, \mathbf{6 - 2 0})$, quer ele seja considerado em termos da sua quididade e essência absoluta, ou seja, enquanto ente (4, 21-33). Esta tese é de difícil argumentação na medida em que entre o nada e o acto completo se interpõem a potência ou os diferentes graus de actualidade. Teodorico começa por apelar à teoria aristotélica da anterioridade lógica (segundo a noção) e no tempo do acto em relação à potência (cf. Met. IX, 8): a partir do momento em que há o acto, há o ente (cf. 4, 2). Quanto ao argumento contrário da privação, ou seja, que o ente em potência se encontra mais próximo do não-ente que do ente pela noção da privação que importa, Teodorico contra-argumenta que, uma vez eliminada esta noção, o ente em potência e o ente em acto têm uma única noção: nem diferem em número nem há entre eles uma composição, ou seja, são um e o mesmo ente (cf. 4, 3). Além disso, a própria noção pela qual uma coisa tende ao seu acto completo fá-lo desde logo distinguir do nada: segundo Aristóteles, "o acto separa" (cf. Met. VII, 13, 1039a7); ou seja, se uma mesma coisa é em potência qualquer um dos contrários, em acto ela é necessariamente um ou o outro deles, pois que segundo o acto (isto é, em termos de realização) a simultaneidade dos contrários é impossível (cf. 4, 4).

Abordados estes três pontos de forma mais geral com o objectivo de apresentar a tese que o que existe em potência se deve tomar na sua determinação em relação ao acto completo, Teodorico vai agora debruçar-se sobre a questão da passagem da potência ao acto no que diz respeito (1.) à geração e (2.) ao ente tomado enquanto ente.

1. Da potência ao acto pela via da geração

1.1. O ente define-se de acordo com a conclusão do processo de geração, a última forma (cf. 4, 7-10):

De acordo com esta perspectiva, a potência e o acto são os dois extremos da geração, distinguindo entre o nada e o ente enquanto ente, ou a última forma, pela qual um ente é uma substância e tem uma existência específica. Mas na medida em que esta perspectiva implica uma sucessão de formas intermediárias e um agente natural que efectue a passagem da potência ao acto, surgem obstáculos. Numa argumentação complexa, bem característica da técnica dita escolástica, refutam-se as opiniões que propõem que a sucessão de formas intermediárias implica a presença de várias formas num ente e a sua respectiva classificação em diferentes géneros subordinados ao mais geral de todos, ao qual pertence o ente em acto. Teodorico concorda que esses intermediários são entes intencionados pela 
natureza, pois que esta nada cria ou intenciona em vão ou por mero acaso, mas a sua concepção é radical: tal como abaixo do ente em potência não há mais nada pelo qual uma coisa possa pertencer a um género e possuir a natureza de ente, do mesmo modo "acima do ente em acto não se encontra nada pelo qual uma coisa estando sob esse acto possa ser formalmente criada sob um acto posterior" $(4,9)$. A radicalidade desta perspectiva reside precisamente nisto: que para Teodorico a classificação de um ente num género depende daquilo pelo qual esse ente é um ente; ou seja, entre o ente e o nada não há de facto qualquer distância: o ente enquanto ente é imediatamente ente. Há, com efeito, entre o género generalíssimo ou mais geral (a substância) e a espécie especialíssima ou mais específica (ex.: homem), géneros subalternos (cf. a Árvore de Porfírio, Figura 1), mas é pela última forma (por exemplo, a alma no caso do homem), pela qual um ente tem um esse specificum, uma existência específica, que um ente se inclui simultaneamente numa espécie especialíssima e num género generalíssimo.

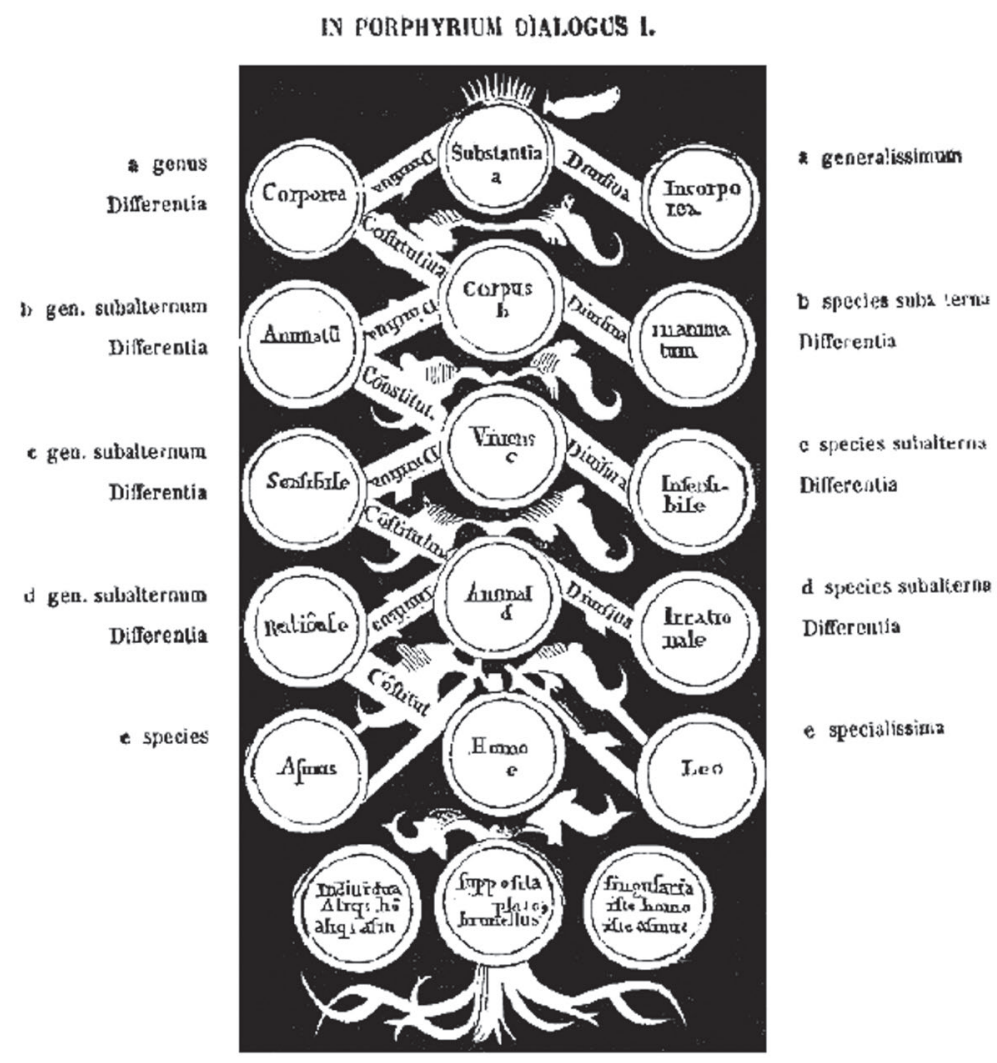

Figura 1 - A Árvore de Porfírio 
1.2. A união da matéria a formas opostas é diferente conforme seja em termos de privação ou de hábito $(4, \mathbf{1 1 - 2 0})$ :

$\mathrm{Na}$ medida em que é a última forma que determina a existência específica de um ente e, logo, a sua classificação em termos de género e espécie, e pois que nos animais vivos esta última forma é a alma, o animal morto não pode pertencer ao mesmo género do animal vivo, visto que a alma, corrompida após a morte, não é forma na carne do animal morto. Isto é assim porque a união da matéria e da forma deve-se a uma determinação essencial; a carne do animal vivo tem em si a determinação potencial a tornar-se carne do animal morto, mas uma vez ocorrida a morte, esta determinação potencial passa a uma determinação essencial que estabelece uma nova união, diversa, desta feita entre a carne do animal morto e a forma da carne. Caso contrário, ou seja, caso a forma da carne do animal vivo se mantivesse no animal morto, este poderia, ou deveria mesmo ressuscitar (cf. 4, 11-13). Por outro lado, o argumento segundo o qual não é necessário que a forma seja diferente, bastando apenas que seja diferente a proporção ou harmonia entre a forma e a matéria, é refutada por Teodorico: a harmonia pela qual uma coisa obtém ou perde uma existência substancial é um aspecto essencial dessa coisa; se essa harmonia é alterada, a essência da coisa é também ela necessariamente alterada, ou seja, ela passa a ser uma outra coisa (cf. 4, 14-16). Há de facto que ter em conta que a matéria ao receber formas opostas se comporta diversamente em termos de privação ou de hábito: em termos de privação, basta que uma forma esteja ausente para que a outra seja recebida (por exemplo, quando do ar se gera o fogo e vice-versa); em termos do hábito, há uma sucessão das formas que tem de se considerar, de modo que uma não pode ser recebida sem que antes uma outra o tenha sido (ex.: para que a matéria receba a forma da carne é necessário que antes ela tenha recebido a forma do sangue). Ora, dá-se que no caso da carne estamos face a uma união em termos do hábito ${ }^{3}$, a qual implica uma ordem irreversível na recepção das formas e na privação das mesmas (embora seja por outro lado uma ordem acidental): uma vez recebida a forma da carne do animal morto, a carne do animal vê-se privada da forma da carne do animal vivo na medida em que a privação implica aqui a corrupção da forma anterior. Se é um ente privado, então é um animal morto, e o retorno à carne do animal vivo é impossível, visto que a privação é precisamente aqui a corrupção da forma anterior ${ }^{4}$ (cf. 4, 17-19).

${ }^{3}$ De facto, trata-se de uma combinação entre os dois tipos de união, pois que se o animal vivo se tornará em animal morto por uma ordem acidental (ver acima), tal como o ar se torna fogo e vice-versa, uma vez recebida a forma do animal morto (que só pode ser recebida após a privação da forma da carne do animal vivo) a ordem é então irreversível: do morto não se forma o vivo, ou seja, aqui a privação é em sentido único, por assim dizer.

${ }^{4}$ Note-se que a problemática da privação assumia nos finais do século XIII uma importância filosófica central na medida em que estava ligada à questão teológica do estatuto ontológico da carne de Cristo (ex.: Henrique de Gandavo, Quodlibet X, q. 5). Note-se, por outro lado, a ausência de qualquer alusão a esta problemática neste tratado de Teodorico. 
2. O ente tomado enquanto ente

2.1. A última forma e as formas intencionais $(\mathbf{4}, \mathbf{2 1 - 2 5})$ :

Nesta perspectiva, o ente é considerado apenas em termos da última forma, ou seja, não se põem considerações nem acerca da geração, nem da passagem da potência ao acto por meio de um agente natural. Os diferentes graus de actualidade e de perfeição, que na perspectiva da geração podem - erroneamente - fazer pensar em diferentes formas, aparecem agora unificados com relação à última forma graças às diferentes intenções formais dessa forma. Teodorico explica isto pelo facto de a uma única noção da matéria correspondente a um género corresponderem diferentes formas em acto pelas quais a matéria, ou o princípio material, se distingue em termos dos entes individuais pertencentes a esse género; esta generalidade ou comunidade face à individualização deve-se então à intenção formalmente real existente nessas formas que tem uma noção única correspondente à unidade desse princípio material: a noção de género primeiro e supremo (genus primum et supremum) tem aqui a sua origem. As intenções formais garantem assim a proporção entre a matéria e a forma pela qual um ente em potência se classifica num género tendo em vista o acto ou a última forma (cf. 4, 21-3). Elas "asseguram" então, da espécie especialíssima até à diferença específica, a pertença de um mesmo ente a um mesmo género de acordo com a sua última forma; não se pode pois falar de diferentes formas, mas apenas das diferentes intenções formais em sucessão de acordo com os diferentes graus de perfeição e actualidade de uma mesma e única forma, a qual é em vista do seu acto; assim, "nada se encontra num género que não se encontre numa sua espécie especialíssima" $(\mathbf{4}, \mathbf{2 5})$.

\subsection{A definição $(4,27-33)$ :}

$\mathrm{Na}$ medida em que - pode-se argumentar - estas formas sucessivas são diferentes umas em relação às outras, não estando além disso contidas umas nas outras, poder-se-ia pois falar da formação de um ente por adição (per aggregationem), mas tal iria contra Aristóteles e Averróis, segundo os quais a unidade do género é garantida pela unidade da definição (cf. 4, 27), a qual, por sua vez, radica na unidade da forma ou do acto específico (cf. 4, 31); esta, por seu turno, radica na unidade da última diferença (cf. ibid.). Teodorico resume assim a tese em discussão:

Uma mesma e única forma "permite" as diversas formas dos géneros organizados de modo hierárquico, mas a partir dessa mesma forma e de acordo com as suas diversas intenções, pelo que essas formas hierarquicamente organizadas não são de facto formas. Logo, não se comportam como tal, ou seja, não existem fora da natureza umas das outras; caso contrário, pôr-se-ia em risco a unidade de uma coisa de acordo com a natureza, a qual é de acordo com a forma, e a definição não seria una (cf. 4, 32). Estas formas intencionais são pois como certos princípios formais de uma única forma completa, mas cada uma importa integralmente o acto da forma, embora o faça de modos diferentes que têm a ver com a maior ou menor determinação da qual resulta a organização hierárquica dos diferentes géneros que se obtém originalmente a partir delas, dos quais cada um deles, porém, importa integralmente o acto específico. Logo, não se relacionam 
umas com as outras em termos de potência e acto. Teodorico conclui em 4, 33: Só a espécie importa de modo determinado o acto específico, de modo que o posterior não é determinável por algo formal, como o ente de modo simples, e as intenções formais relacionam-se umas com as outras pela ordem do indeterminado ou menos determinado para o determinado ou mais determinado numa única e mesma forma, pelo que, quanto àquilo que são, não são em realidade senão uma e a mesma forma.

A última frase de 4, 33 resume de forma algo abrupta a argumentação acima: as diversas intenções formais que existem numa forma única enquanto última forma só são diferentes ou múltiplas pela razão; mas isto não significa que elas sejam meros entes de razão: na natureza, elas constituem uma forma única, correspondente a um ente de facto. Este carácter algo abrupto é porém suavizado com a interessante comparação que Teodorico traça entre o modo de ser (modus essendi) na questão que é aqui tratada, ou seja, tomando o ente enquanto ente, e o modo de formar-se (modus fiendi) no processo da geração, tratado anteriormente: assim como neste último a matéria de uma coisa que progride para o acto completo participa cada vez mais da perfeição do acto último e completo de modo que da potência se forma o acto, assim no primeiro dos diferentes graus de perfeição e actualidade segundo os quais se obtêm os diferentes géneros a que uma coisa "vai pertencendo" se forma um único ente pela perfeição última e completa do acto específico; em nenhum dos casos se forma uma composição real, ou seja, nem no primeiro caso uma composição real se forma entre os diferentes graus de perfeição e os diferentes géneros, nem no segundo se forma uma composição real entre a potência e o acto. Por outras palavras, a operação natural e a operação do intelecto parecem equivalentes no sentido em que terminam num ente único e uno.

De 4, 35 a 4, 40, Teodorico apresenta e refuta argumentos adicionais que têm a ver com aparentes problemas que surgem na consideração da passagem da potência ao acto, nomeadamente no que diz respeito à unidade da essência, mas do ponto de vista da noética a conclusão principal já foi tirada: as intenções formais, a última forma, a definição, todas elas em vista do acto completo pelo qual um ente difere em primeiro lugar do não-ente ou do nada, são entes reais; embora sejam entes de razão, ou seja, entes que existem somente por uma operação do intelecto humano, não correspondem por isso a meros entes de intenção segunda, tendo pelo contrário o mesmo estatuto que as coisas de intenção primeira. 


\section{SOBRE A ORIGEM DAS COISAS CATEGORIAIS DE TEODORICO DE FREIBERG}

\section{Capítulo 3}

(No qual se mostra a noção comum dos entes que são classificáveis num género e por que razão alguns são removidos da classe dos géneros)

(1) Agora temos de considerar a noção dos entes que podem ser classificados num género ${ }^{5}$ e por que razão alguns são excluídos da classe de género de acordo com aquilo que o metafísico considera ser os géneros dos entes.

(2) Há três aspectos que têm de estar simultaneamente presentes num ente para que em si e originariamente ele possa encontrar-se na classe de um género.

(3) Em primeiro lugar, é necessário que seja uma coisa natural ou que importe uma coisa natural: com efeito, os entes que pertencem a um género de acordo com a já mencionada consideração são em si mesmos e fazem parte de uma classe por si mesmos, o que só se aplica às coisas naturais.

(4) Mas estes entes importam uma coisa natural ou no modo do subsistente em si mesmo, o modo próprio da substância, ou no modo daquilo que determina ou modifica formalmente uma substância em termos de uma qualquer operação natural, e isto activa ou passivamente. O que de facto acontece de três modos.

(5) De um modo na medida em que estas determinações são certas naturezas e são princípios de tais operações ou movimentos em si quanto àquilo que principalmente se significa pelo nome; e estes entes são quantidades e qualidades naturais das coisas.

(6) De um outro modo na medida em que alguns entes se comportam de um modo como que causal em relação aos movimentos mencionados dos entes ou aos seus princípios e são criados a partir destes por uma razão agente; o que faz com que tanto na realidade como no intelecto eles tragam consigo as naturezas mencionadas com relação a uma substância ao determiná-la. Deste tipo são as relações e alguns entes dos quais acima se disse que se encontram no género da quantidade e outros no género da qualidade.

(7) Num terceiro modo são certos entes que em relação aos ditos movimentos são ou operações naturais das coisas, ou princípios delas - mais precisamente com respeito à própria substância - em termos de determinações naturais destas como num modo circunstancial. Pelo que se verifica que os mesmos entes tanto na realidade como no intelecto trazem consigo as naturezas mencionadas ao determinarem a substância, com o intelecto, contudo, a introduzir neles a entidade que principal e formalmente é significada pelo termo e pela qual eles são classificados em géneros determinados e próprios de acordo com as próprias noções. E estes são os seis géneros das coisas que o autor de Os Seis Principios ${ }^{6}$ chama formas

\footnotetext{
${ }^{5}$ Ou seja, que podem constituir uma das dez categorias.

${ }^{6}$ L. sex princ. I, 14; ed. Minio Paluello - Dod, 38.
} 
com uma origem externa; acerca das quais diz Boécio no livro Sobre a Trindade ${ }^{7}$ que estas não significam coisas, mas sim circunstâncias das coisas ${ }^{8}$.

(8) O segundo aspecto que se considera num ente classificável num género de acordo com uma classe directa de género é que ele deve ser um ente completo uma vez alcançada a sua perfeição, a qual lhe é própria segundo a sua própria noção e o modo da sua essência, nomeadamente ao ter a sua <própria> espécie. A causa disto é que a noção de ente, que é distinta de acordo com os diferentes géneros, é a primeira e a mais formal de todas as intenções, como se disse, graças à qual uma coisa primeiro difere formalmente do nada; o que não é o caso senão segundo o acto completo da sua quididade e essência, como abaixo se mostrará. A noção de cujo complemento ${ }^{9}$ e perfeição em qualquer um destes entes é que ele é de modo simples e em si mesmo um ente; este ente é aquele que é intencionado de modo simples e em si mesmo pela natureza, e tais entes pertencem ao tipo em que cada um tem a sua entidade e o seu complemento de acordo com a espécie de modo absoluto e em si mesmo, e não por acidente.

(9) Em terceiro lugar devemos ter em atenção que para que certos entes pertençam a um mesmo género é necessário que participem de uma noção comum do mesmo; não podem pertencer a uma mesma classe senão de acordo com algo comum entre eles.

(10) Esta noção comum pode ser tomada de dois modos: de um modo de acordo com a natureza da coisa tomada absolutamente, e de um outro modo em termos de uma analogia.

(11) No primeiro modo, a saber, tomando a noção do animal de acordo com a natureza do animal em si e absolutamente. O que não é o caso senão a partir do facto que nos entes que pertencem a uma mesma classe segundo esse género se encontra algo que, sendo de uma só noção e natureza, é o princípio de todo esse género. E este princípio primeiro e radical nas coisas geráveis e corruptíveis é a matéria, e de um modo geral em todos os entes que pertencem a uma mesma classe pelo género este princípio tem de ser a matéria ou algo tendo o carácter e o modo da matéria. De facto, o acto simples ${ }^{10}$ em entes diversos não

${ }^{7}$ Boécio, De Trin. IV; ed. Steward-Rand, 22-4: Iamne patet quae sit differentia praedicationum? Quod aliae quidem quasi rem monstrant aliae vero quasi circumstantias rei[;] quodque illa quae ita praedicantur, ut esse aliquid rem ostendant, illa vero ut non esse, sed potius extrinsecus aliquid quodam modo affigant.

${ }^{8}$ Com o termo circumstantias (ver nota imediatamente acima) Boécio pretende realçar o carácter extrínseco destas seis categorias; por exemplo, dizer de um homem (substância) que se encontra na praça pública é uma predicação diferente daquela pela qual se diz dele que é branco ou alto, pois que enquanto ele pode ser designado por uma destas propriedades que lhe dizem "directamente" respeito, não o pode ser pela referência ao lugar em que se encontra.

${ }^{9}$ Isto é, que completa.

${ }^{10}$ Actus simplex, a actividade de uma faculdade que visa aquilo que em si mesmo é o objecto dessa faculdade; por exemplo, pensar (intelligere) é o acto simples da faculdade do intelecto. 
se distingue senão de acordo com a diferença absoluta e de todos os modos que separa fora do género, pois que o acto simples difere do completamente simples. Mas porque uma coisa não é determinada em relação a um qualquer género nem é colocada num género tomando em consideração a matéria, mas sim em termos de um qualquer acto formal - como diz o Filósofo no livro VIII da Metafisica ${ }^{11}$ que o termo género se refere mais à forma do que à matéria -, eis porque, visto que a noção do género é concebida de modo completivo do facto que esse mesmo princípio fundamental e original do género, a saber, a matéria, é distinguido por diversas formas ${ }^{12}$, é necessário encontrar em todas as formas uma intenção correspondente à unidade da matéria ou do princípio material. O que faz com que deste modo partilhem todos de uma só noção e pertençam assim consequentemente a uma mesma classe pelo género. $\mathrm{E}$ assim o filósofo metafísico concebe verdadeira e propriamente a noção de género de acordo com o que diz o Filósofo no livro $\mathrm{X}$ da Metafisica $^{13}$, que os entes corruptíveis e os incorruptíveis não pertencem ao mesmo género, nem os discretos e os contínuos, e por aí fora.

(12) Num outro modo, a noção comum de um género não é tomada de acordo com a natureza de uma coisa em si, como se disse, mas em termos de uma analogia que se chama proporcionalidade ${ }^{14}$. E assim a maior parte das vezes o lógico constitui a unidade de um género de acordo com a probabilidade. Por exemplo, ele toma a noção do género que é a substância tanto nas coisas incorpóreas como nas corpóreas a partir da noção de substar, embora o termo "substância" seja estabelecido ${ }^{15}$ a partir da noção de subsistir ${ }^{16}$ : este termo ${ }^{17}$ vem do modo de substar que se encontra proporcionalmente nestas coisas; assim como estas ${ }^{18}$ substão aos seus < próprios $>$ modos e propriedades ou até mesmo acidentes, aquelas ${ }^{19}$ substão aos seus. E do mesmo modo ele argumenta que a natureza do corpo, o qual pertence ao género da substância, é una em todos os corpos pela razão que todos os corpos são delimitados do mesmo modo pelas suas dimensões, e de acordo com isto diz ele que todos os corpos pertencem a um mesmo género; do mesmo modo concebe uma natureza comum nos entes contínuos e nos discretos; do mesmo modo noutros. E em relação a este segundo modo vê-se que os entes se distinguem e classificam logicamente e de acordo com os modos de falar

11 Aristóteles, Met. VIII, 3, 1043a36-7.

12 Parafraseando: os géneros distinguem-se primeiramente pela forma, mas são-no ainda - para a perfeição final (completive) - pela matéria na medida em que esta é distinguida por formas diferentes.

13 Aristóteles, Met. X, 10, 1058b28-9; 1059a9-10.

$14 \mathrm{Ou}$ seja, uma igualdade de relação.

15 Mais propriamente: seja imposto (cf. o termo impositio na lógica medieval como o estabelecimento do significado).

${ }^{16}$ Cf. introdução ao capítulo 2 para as consequências metafísicas para os "acidentes" segundo a substância seja tomada como aquilo que subsiste ou como aquilo que substá.

17 Substância.

${ }^{18}$ As coisas corpóreas.

${ }^{19}$ As coisas incorpóreas. 
prevalecentes ${ }^{20}$, como diz o Comentador em Sobre o Livro V da Metafísica ${ }^{21}$ e em Sobre o Livro III da Física ${ }^{22}$, somente em dez géneros, os quais chamamos categorias; e o Filósofo indica isto em Categorias ${ }^{23}$, onde diz ter enumerado os modos da qualidade "que se costumam dizer" 24 . De acordo com o primeiro destes modos, ou seja, considerando as coisas de acordo com as suas naturezas próprias, elas não são obrigadas a este número de géneros, mas os entes que pertencem a um género por uma razão lógica não pertencem na verdade a um único género, como é evidente sob todos os aspectos em relação ao corpo, o qual pertence ao género da substância, e em relação a muitos outros.

(13) Após estas considerações é <agora> evidente por que razão se diz simplesmente que alguns entes não pertencem a nenhum género, enquanto outros, ainda que não se encontrem em nenhuma classe de género originariamente e em si mesmos, podem porém pertencer a esta classe por meio de uma redução ${ }^{25}$.

(14) Tendo em atenção a primeira destas três condições mencionadas ${ }^{26}$, a saber, que o ente classificável num género importa uma coisa natural, as coisas de razãa o, que são coisas de intenção segunda, não pertencem a um género: de facto, elas não importam nenhuma natureza de ente.

(15) Pela mesma razão aqueles que chamamos os pós-predicamentos ${ }^{27}$ são também eles excluídos da classe dos géneros: de facto, nenhuma determinação natural tem existência em algo pelo facto de ser simultâneo a outro no tempo ${ }^{28}$ ou no espaço, ou por ser anterior em dignidade ${ }^{29}$ ou no tempo, a não ser talvez por acidente; e se alguns deles importam uma qualquer natureza na substância ou em relação à substância, por esta razão não são excluídos da classe ou da natureza de um género. Mas estes são determinados e distintos mais pelo modo de falar prevalecente e pela probabilidade que de acordo com a verdade. Se estes pós-predicamentos são algo para o metafísico, não são porém senão acidentes em geral, ou entes com o modo geral de acidentes das coisas naturais classificáveis num género, as quais são propriamente entes.

\footnotetext{
20 Secundum famositatem.

${ }^{21}$ Averróis, In Aristotelis Met. V, comm. 18; ed. Ponzalli, 161.

${ }^{22}$ Averróis, In Aristotelis Phys. III, comm. 4; Venetiis 1562, 87rD-E.

${ }^{23}$ Aristóteles, Cat. 8, 10a25-6.

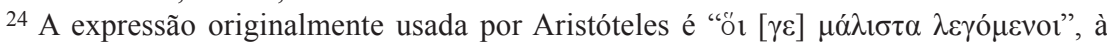
letra, "os mais ditos", exprimindo a ideia "aqueles dos quais se fala mais frequentemente".

${ }^{25}$ Per reductionem. Segundo o pensamento escolástico, algo pertence a um género de modo essencial e em si mesmo (per se) ou por redução, o que implica uma natureza "diminuta" ou imperfeita (cf., por exemplo, Tomás de Aquino, Summa theol. III, q. 63 a. 2 co.).

${ }^{26}$ Cf. 3.3 acima.

27 Aristóteles, Cat. 10-15, 11b15ss. Os pós-predicamentos (postpraedicamenta), assim chamados pela tradição latina porque se seguiam às categorias (praedicamenta), são o oposto (oppositio), o anterior e o posterior (prioritas et posterioritas), o simultâneo (simultas), o movimento (motus) e o ter ou a posse (habitus).

28 Aristóteles, Cat. 13, 14b24-15a12.

${ }^{29}$ Aristóteles, Cat. 12, 14a26-b23. 
(16) Pela mesma razão também as propriedades dos entes são excluídas da classe de género, embora pertençam ao mesmo género das coisas-sujeito ${ }^{30}$ de acordo com a noção pela qual são propriedades desses entes e acidentes em si mesmas. Falo das coisas que existem noutras em termos da própria quididade e essência, como se disse acima.

(17) Tendo em atenção a segunda das condições mencionadas ${ }^{31}$, onde se falou do complemento de um ente classificável num género, os princípios intrínsecos dos géneros não pertencem a um género senão por meio de uma qualquer redução, na medida em que se encontra neles algo da noção dos entes completos como por meio de um qualquer começo e origem. De facto, eles não importam um ente completo em termos do acto específico que é necessário para que algo seja de modo simples e em si mesmo classificável num género pela noção mencionada.

(18) E nada obsta, se alguém objectar, que aqueles entes que pertencem de facto a um género recebem contudo graus de mais e menos, como o branco, o quente e outras coisas semelhantes, razão pela qual não parecem ser entes completos, o aspecto $^{32}$ pelo qual são classificáveis num género.

(19) Mas devemos saber que se diz de dois modos que alguns entes recebem graus de mais e menos. De um modo de acordo com o grau e a progressão para o acto final pelo qual uma coisa tem a sua <própria> espécie; e deste modo, como dizem alguns, algumas substâncias recebem graus de mais e menos, e assim nada pertence simplesmente e de facto a um género a não ser que esteja no seu acto final, pelo qual tem uma existência específica. Diz-se de outro modo que alguns entes recebem graus de mais e menos de acordo com a intensificação e a diminuição ${ }^{33}$ de uma espécie já estabelecida; e deste modo alguns entes podem correctamente ser integrados num género em termos do seu acto específico, o qual têm, embora não tenham o último grau de perfeição no que respeita à intensidade da espécie estabelecida ${ }^{34}$. A objecção com respeito ao branco e ao quente e às outras coisas semelhantes funda-se nisto.

(20) Tal como se disse acerca dos princípios dos entes, o mesmo é igualmente verdade no caso de certos entes incompletos, como o são os embriões e outras coisas semelhantes que se encontram num processo de geração. Pertencem ${ }^{35}$ ao mesmo género dos entes completos não pela forma substancial que então ${ }^{36}$ têm,

\footnotetext{
${ }^{30}$ As coisas que servem de sujeito.

${ }^{31}$ Cf. 3.8 acima.

32 Ser entes completos.

33 Intensio et remissio.

${ }^{34}$ Resumindo: Teodorico opina que os entes que apresentam diferentes graus de menos ou mais (por exemplo, graus de brancura ou de calor) podem pertencer a um género se esses graus o forem de uma espécie já estabelecida, embora lhes falte o último grau de perfeição dessa espécie; se se considerar apenas o último acto, de acordo com o qual um ente tem a sua existência específica, então entes com graus de intensificação ou diminuição não pertencerão a um género (cf. 3, 19).

35 Por redução (reducuntur).

${ }^{36}$ Enquanto embriões.
} 
visto que esta não constitui um ente completo na natureza, nem é intencionada em si mesma pela natureza, mas de acordo com o facto que a matéria participa em certa medida no acto e na noção da forma final, a qual é o fim da geração. E porque por esta participação a forma final não é senão ainda uma existência potencial, a qual não pode revelar-se na natureza sem o acto completo, eis porque a natureza revela a forma de embrião, sob a qual no entretanto está a matéria, até este se apresentar na última determinação que é a necessidade de ser simplesmente pelo acto da forma intencionada, desaparecendo então a forma de embrião.

(21) Mas põe-se aqui o seguinte problema: se alguns entes pertencem ${ }^{37}$ a um mesmo género pelo facto de se encontrarem na relação da potência ao acto, dado que nos entes geráveis e corruptíveis tudo é em potência tudo, ainda que num grau diferente de maior ou menor análoga potência, parece que os entes geráveis e corruptíveis não pertencem a géneros e espécies determinados e que cada um pode pertencer ${ }^{38}$ a um género qualquer.

(22) Se se responder que do número daqueles que são entes em potência só podem pertencer ${ }^{39}$ a um mesmo género e espécie aqueles que se encontram numa certa relação recíproca em termos da progressão natural do menos perfeito ao mais perfeito, somos então confrontados com uma absurdidade. De facto, a partir desta perspectiva, visto que os elementos são em vista do ente composto, os entes compostos em vista dos entes animados, e que do mesmo modo em termos do progresso e ordem da natureza o alimento dos animais é composto de elementos, do alimento se faz o sangue, do sangue a carne, parecem todos estes pertencer a uma mesma classe pelo género e pela espécie. O que é obviamente falso: eles são diferenciados em espécie pelas suas formas substanciais próprias. O mesmo parece ser verdade no caso do embrião e do animal que é gerado a partir do mesmo em termos de uma espécie determinada.

(23) Mas devemos compreender que, visto que aquilo que é em potência tem a sua noção definitiva não só pela matéria, se a tiver, mas também do acto para o qual está determinado, é necessário que assim sendo a potência e o acto pertençam a uma classe pelo género. Acontece todavia no caso de certos entes que o que é em potência e o que é em acto se encontram em géneros e espécies próprios e diferentes de acordo com a noção própria das suas formas substanciais; em certos outros porém verifica-se que embora estejam sob formas substanciais próprias e diferentes, pertencem contudo simplesmente ao mesmo género e à mesma espécie.

(24) De modo a tornar isto claro temos de ver que, como se disse, o ente classificável num género é de modo simples e em si um ente completo em termos da espécie, um ente cuja noção da completude consiste em que ele é um ente em si mesmo ao ter a sua forma substancial do agente em si mesmo em relação ao fim intencionado em si mesmo pela natureza. Falo agora do fim que é um fim intrínseco, a operação própria de uma coisa que umas vezes se encontra na

\footnotetext{
${ }^{37}$ Por redução (reducuntur).

38 Por redução (reducibile sit).

39 Por redução (reducibilia sunt).
} 
natureza em vista da perfeição do operante, como nos entes completos, como nos animais e em coisas semelhantes, mas outras vezes a operação própria de uma coisa é-lhe determinada pela natureza somente com vista a outra coisa, e estes entes são instrumentos da natureza, como as sementes e outras coisas semelhantes. Como os entes de que falámos se encontram nos elementos, que são partes do mundo, e nas coisas compostas, igualmente quer nos animais quer talvez em todos os entes geráveis e corruptíveis, é obvio que estes são determinados para os próprios géneros e espécies.

(25) Quanto à objecção, respeitante à potência e ao acto, que tudo pode vir do que quer que seja, devemos dizer que embora tudo possa vir do que quer que seja, não se dá o caso que tudo esteja em potência em relação ao que quer que seja a não ser que se encontre numa tal afinidade ${ }^{40}$ que possa ser realizado em acto por um agente, como diz o filósofo no livro IX da Metafísica ${ }^{41}$.

(26) Temos de saber, porém, que, como é defendido pelo Filosófo no livro VIII da Metafisica ${ }^{42}$ e a partir do livro VIII da Física ${ }^{43}$, nas coisas geráveis a unidade de cada ente, tal como o próprio ente, é em virtude de uma causa agente na qual tanto a entidade como a unidade se encontram de modo mais formal e perfeito. Um ente em potência nesse modo mencionado, a saber, no qual pode ser realizado em acto por um agente, pode encontrar-se na natureza de três maneiras.

(27) Num modo em que esse ente é levado a esse grau de potência por um agente comum ou universal que é capaz de levar essa potência ao acto completo; o agente deste modo é uma faculdade ou certas faculdades elementares, por exemplo se o fogo produz carvão a partir da madeira e cinzas a partir do carvão, ou um qualquer agente produz ar a partir de água e fogo a partir do ar. Digo que estes entes, embora sejam entes singulares em potência a tornar-se entes singulares, não pertencem necessariamente a uma mesma classe pela espécie. Por falta de um mesmo agente determinado falta-lhes a unidade determinada da potência ao acto que é necessária para a unidade segundo a espécie.

(28) Encontra-se ainda o ente em potência num outro modo no qual esse ente é levado a esse grau de potência por um determinado agente diferente do agente determinado que leva ao acto completo, como por exemplo o mênstruo, que é um animal em potência, é levado a esse grau de potência por uma faculdade activa diferente da faculdade formativa que a partir do mênstruo produz o animal e a qual se encontra instrumentalmente no esperma. $\mathrm{E}$ os entes que são em potência deste modo não pertencem necessariamente à mesma espécie que os entes em acto em relação aos quais eles são em potência: com efeito, falta-lhes a unidade da potência ao acto por falta de unidade nos diferentes agentes. Pelo que o alimento, o sangue, a carne e outras coisas que tais das quais falamos não pertencem à mesma espécie, ainda que os seus entes singulares estejam relacionados com entes singulares por essa afinidade da potência, como se disse.
40 Propinquitas.
${ }^{41}$ Aristóteles, Met. IX, 7, 1049a1-18.
42 Aristóteles, Met. VIII, 6, 1045a30-31.
${ }^{43}$ Aristóteles, Phys. VIII, 5, 247b9-10. 
(29) Num outro modo ainda encontra-se um ente no grau de potência referido mas por um mesmo agente determinado e próprio que realiza o acto completo, como acontece no caso dos embriões; e um tal agente não age senão a partir de um determinado princípio potencial em vista de um determinado fim por um meio determinado que não se encontra fora dessa relação. E neste modo a partir da unidade do agente temos de certo modo a unidade da potência ao acto que é necessária para a unidade não só do género mas também da espécie; e por esta razão estes entes pertencem a uma mesma classe quer pelo género, quer pela espécie, como se disse.

(30) Se porém houver um ente em potência activa cuja acção se encontre na natureza só em vista de outro ente, como o são os instrumentos da natureza como o esperma e outras coisas semelhantes, embora este ente não seja em vista de si próprio nem a sua operação pertença por isso à sua perfeição em si mesmo de acordo com a intenção da natureza, não é contudo por isso necessário que pertença ${ }^{44}$ à mesma espécie que o ente que age por si mesmo, visto que por vezes falta a unidade formal de tais entes activos e passivos que é necessária para a unidade da espécie, como se vê no caso do esperma e do animal. Pode porém dizer-se que pertence de certo modo à mesma espécie não como existindo dentro da classe do género ou da espécie, mas extrinsecamente, graças à sua operação, determinada para essa espécie pela natureza.

(31) Igualmente, como se disse acerca dos entes em potência, também os entes privados como o animal morto e outras coisas semelhantes pertencem ao mesmo género que os entes dos quais eles são privações, originalmente ${ }^{45}$ decerto a partir da natureza e da noção do sujeito, mas formalmente e de modo completivo pela noção de privação. A privação tem a $<$ sua $>$ noção a partir da forma e do hábito ${ }^{46}$ em relação ao qual ela é uma privação e por isso devem pertencer a uma mesma classe: a privação substitui no sujeito a forma substancial. Pelo que no caso destes entes, a saber, os entes privados, para que pertençam a um género $a$ privação está no lugar da forma substancial. Não pertencem ${ }^{47}$ a um género pela forma substancial que então existe neles, visto que são entes privados, como o animal morto pela forma do corpo ou da carne que então se encontra nele: esta forma é criada e intencionada por acidente pela natureza, pois que não é o princípio de nenhuma operação intencionada em si pela natureza, mas tão-somente a forma por meio da qual um ente se encontra em decomposição de modo a que se alcancem os princípios da natureza, o fim pelo qual a corrupção de um ente possa ser a geração de outro. Por isso estes entes podem pois pertencer ao género graças ao qual originalmente se relacionam com a forma em virtude da qual em si e de modo simples um ente pertence a um género. Esta é a privação graças à qual um ente se relaciona em primeiro lugar com uma forma, como um ente em

44 Por redução (reducatur).

${ }^{45}$ Ou seja, em termos da sua origem.

${ }^{46}$ Aquilo (a qualidade) que se tem, por oposição a falta ou privação; cf. por exemplo Aristóteles, Met. IV, 6.

${ }^{47}$ Por redução (reducuntur). 
potência em primeiro lugar se relaciona com o acto da forma por meio daquilo que é em potência; e deste modo pode pertencer ${ }^{48}$ ao mesmo género.

(32) Quando digo "a forma intencionada por acidente pela natureza", chamo natureza não só o princípio primeiro de todos os entes, mas em especial a duração determinada e especifica de cada ente que delimita a existência de cada coisa gerável, pois que assim como ao gerar um ente intencionado em si pela natureza esta intenciona a existência e a realização ${ }^{49}$ da coisa segundo o acto da forma, ao corromper <um ente> ela intenciona em primeiro lugar a corrupção ou a privação da forma, e não a forma a ser introduzida sob a qual está o ente privado ao qual não compete em si mesmo ter uma duração na natureza assim como também não é um ente em si na natureza, como se disse. E isto é o que o Filósofo quer dizer no livro VIII da Metafísica ${ }^{50}$, onde diz que o vivo não é a matéria do morto, nem o vinho a matéria do vinagre, nem a matéria recebe essencialmente a forma do morto ou do vinagre, mas acidentalmente, de acordo com o processo de corrupção do animal e do vinho.

(33) Mas se considerarmos nos entes privados a noção e a natureza do sujeito no qual em primeiro lugar e por essência a privação toma o lugar da forma substancial, então pertencem não só ao mesmo género que os entes dos quais eles são privações, mas também à unidade em termos da espécie, e até se reduzem de certo modo à mesma entidade numérica ${ }^{51}$. A noção dos opostos em termos privativos é que eles são opostos de acordo com a forma com relação ao sujeito tanto na realidade como pela razão: com efeito, o privado é aquilo mesmo que era o formado ${ }^{52}$. Visto que pois no ente privado neste modo o sujeito e a privação são por essência, tal como no ente formado o são o sujeito e a forma, a forma e a privação sendo excluídos de um sujeito comum aquilo que resta quanto àquilo que é por essência é uno ${ }^{53}$, embora por acidente possa diferir, nomeadamente pela forma substancial que se encontra por acidente no ente privado, como se disse. Mas seja de acordo com este mesmo ente por acidente ou com a forma substancial que é constituída por acidente no ente privado, este ente é classificado ${ }^{54}$ juntamente com o ente formado não só de acordo com a noção da relação segundo a qual esta forma sucede aquele, mas pelo facto que tudo aquilo que é por acidente é redutível àquilo que é em si quer se entenda por aquilo que é em si a forma do ente formado, o sujeito comum, ou até a própria privação: são todos por essência, embora cada um à sua maneira.

(34) Contudo, quando se disse que a privação é por essência não se quer com isto dizer que a privação seja um ente, mas que a privação é a conclusão da corrupção da forma, a qual corrupção é por essência, assim como a forma é a

\footnotetext{
48 Por redução (est reducibile).

${ }^{49} \mathrm{Ou}$ perfeição (complementum).

${ }^{50}$ Aristóteles, Met. VIII, 5, 1044b34-1045a2.

${ }^{51} \mathrm{Ou}$ seja, são um e o mesmo ente.

52 Que tinha uma forma.

53 Ou seja, é o mesmo sujeito.

54 Num género ou espécie.
} 
conclusão da geração, a qual é por essência. A corrupção da forma é por essência na medida em que existe no sujeito graças a uma causa agente essencial de acordo com a natureza dos próprios princípios deste, como se disse.

(35) De acordo com estas considerações é evidente quão mais conveniente e correctamente se concede que o corpo do animal morto é o mesmo que o do animal vivo, embora segundo os filósofos se possa conceder e seja verdade que a carne morta não é carne senão equivocamente ${ }^{55}$, nem é a mesma que era anteriormente ${ }^{56}$. Isto é com efeito verdade se se considerar a forma substancial da carne morta em si e não em termos da referida redução que é concebida a partir da intenção da natureza ao constituir estes entes. Considera-se a mesma analogia respeitante à identidade e a distância por equivocação respeitante à diferença no caso dos membros funcionais, como o olho, a mão e outros que tais na medida em que segundo o Filósofo ${ }^{57}$ são constituídos nas suas funções no corpo vivo e são privados delas no corpo morto. Pelo que o animal morto não pode pertencer ao género do corpo inanimado, como imaginam alguns ${ }^{58}$, pertencendo pelo contrário ao género de animal, como mostra Agostinho de modo geral acerca de todos os entes privativos no livro $\mathrm{V}$ de $A$ Trindade ${ }^{59}$. Com efeito, uma coisa é a noção do inanimado e da privação que ele implica, caso em que ele compartilha com o animado este género que é o do $\operatorname{corpo}^{60}$, mas outra coisa é a noção do animal morto e da privação que ele implica: a privação e a forma, de acordo com o que as diferenças dividem um determinado género, não se consideram segundo a sua sucessão uma em relação à outra num sujeito segundo a natureza mas somente de acordo com o facto que um ente, a distinguir entre muitos, pela natureza primeiro pertence a uma primeira divisão na qual os entes se distinguem uns em relação aos outros; mas a privação que o animal morto implica e a forma oposta não pertencem a este modo, como é evidente.

(36) Tendo em vista a terceira das condições mencionadas ${ }^{61}$, o princípio primeiro de todos os entes não é determinado em relação a nenhum género. É necessário, como se disse aí, que os entes que pertencem a uma mesma classe pelo género enquanto tal tenham uma mesma noção <em comum>. Mas nenhum

55 Dizemos que duas coisas (mais ou menos) diferentes (ou distantes entre si) são a mesma equivocamente quando em comum entre si só têm o substantivo que as designa.

56 Quando o animal era vivo.

57 Aristóteles, Met. VII, 11, 1036b30-32; Meteor. IV, 12, 389b31-390a1, 390a10-13. Isto quer dizer que a matéria não é determinada somente pela forma, mas também pela função, pelo menos no caso dos organismos vivos, como seria de esperar na filosofia "cinética" e "organizacional" de Aristóteles, aspectos que por sua vez se integram no hilemorfismo que a caracteriza.

58 E.g.: Mateus de Aquasparta, Quaest. disp. de fide VI ad 10; ed. Quaracchi 1957, 160; Quaest. de an. VI q. 2 ad 13; ed. Gondras, 261.

${ }_{59}$ Agostinho de Hipona, De Trin. V, 7, n. 8; PL 42/915-6.

$60 \mathrm{O}$ género do corpo divide-se em dois subgéneros, o dos corpos animados e o dos corpos inanimados.

${ }^{61}$ Cf. 3.9 acima. 
dos entes que pertencem a uma mesma ordem de acordo com uma mesma noção $<$ em comum $>$ pode ser o princípio de toda essa ordem pela razão que cada um dos entes que pertencem a uma mesma ordem tem a noção da parte e do existente em potência com respeito a toda a ordem. O princípio primeiro é o princípio e a causa de toda a ordem da natureza. Por isso é necessário que ele se encontre fora de toda a ordem da natureza, pelo que não pode ser determinado em relação a nenhum género. Visto que ele é um princípio extrínseco a toda a ordem, eis porque é necessário que falte à sua natureza aquilo que é o princípio intrínseco pelo qual todos os entes que $o^{62}$ partilham têm uma mesma noção e pertencem logo a uma mesma classe pelo género, como se disse acima.

(37) Igualmente, de acordo com isto, se há entes simples nas suas essências, como os filósofos pensavam acerca das inteligências, estas, porque não partilham de nenhum princípio natural, não pertencem por isso a nenhum género, embora necessariamente pertençam à ordem de tudo o que é, como se mostra no Tratado acerca das Causas $^{63}$.

\section{Capítulo 4}

(Nesta parte mostra-se como o ente difere em primeiro lugar do nada ou do não-ente, bem como algumas coisas acerca da unidade e da ordem das formas)

(1) Há porém quem tenha dúvidas acerca do que se disse acima, a saber, que o ente difere do nada ou do simplesmente não-ente em primeiro lugar pelo seu acto completo ${ }^{64}$. Tal não parece ser verdade, visto que entre o ente em acto completo e o nada ou o simplesmente não-ente há o ente em potência que, encontrando-se num estado intermediário, parece estar mais próximo do não-ente de modo simples que daquilo que é o ente em acto.

(2) Mas temos de saber, de acordo com o Filósofo no livro IX da Metafísica ${ }^{65}$, que $o$ ente em potência não tem nem existência ${ }^{66}$ nem definição senão em termos do acto para o qual está determinado. Pelo que em virtude do acto do qual algo já participa e de acordo com a sua própria noção este ente em potência tem a noção de ente e aquilo pelo qual ele difere do simplesmente não-ente; e assim em primeiro lugar e principalmente a noção tanto de ente como da diferença em relação ao nada encontram-se no acto ${ }^{67}$.

${ }^{62}$ Princípio intrínseco.

63 Referência não encontrada.

64 Actus completus, a realidade perfeita e completa, o ser verdadeiro de uma coisa.

${ }^{65}$ Aristóteles, Met. IX, 8, 1049b10-11.

66 Esse.

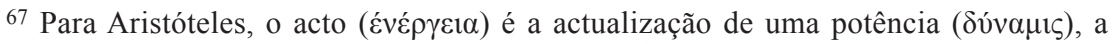
concretização e/ou a actividade de concretização de uma possibilidade, ou ainda a elimi-

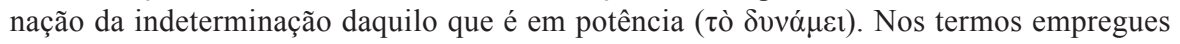


(3) Em relação à objecção que o ente em potência está mais próximo do não-ente <que do ente> deve dizer-se que isto é verdade pela noção da privação que o ente em potência importa, pela qual nem tem a noção de ente nem por ela difere do não-ente. Uma vez < porém> eliminada de facto a privação de um ente em potência, aquilo que está em potência e o ente em acto têm uma única noção; segundo a noção de ente nem diferem em número, pois que o ente em acto não é uma adição ao ente em potência, nem há entre eles nenhuma composição, a potência tornando-se acto no processo da geração. Falo da potência e do acto porque um ente tomado como um todo é primeiro em potência e em seguida em acto.

(4) Além disso, o mesmo, o oposto e o diferente pressupõem o ente; assim sendo, aquilo que não é senão em potência nem é o mesmo que outra coisa nem difere de outra coisa senão em potência. Logo, um ente não difere em acto do nada senão por algo pelo qual ele é um ente em acto: pelo que o Filósofo diz no livro VII da Metafisica ${ }^{68}$ que somente o acto separa ${ }^{69}$. Pelo que tal como uma

pelo Estagirita, "o acto é para uma coisa o facto de existir em realidade e não do modo que dizemos que ela existe em potência, quando dizemos, por exemplo, que Hermes [isto é, uma estátua de Hermes] se encontra em potência na madeira, ou que a meia linha se encontra na linha inteira na medida em que pode ser tirada dela, ou quando chamamos sábio em potência aquele que nem sequer especula, se ele tem a faculdade de especular; o outro modo de existir é a existência em acto" (Met. IX, 6, 1048a30-35; nossa tradução, seguindo de perto a tradução de J. Tricot em Aristóteles, La métaphysique, v. II, Paris, Vrin, p. 499). Nesta perspectiva, um bloco de mármore ou uma porção de bronze são em potência uma estátua; esta encontra-se neles em potência. Assim, a potência está intimamente ligada à matéria, enquanto o acto se encontra ligado à forma: o acto é, por assim dizer, a informação da matéria, o introduzir-lhe ou "dar-lhe" uma forma definitiva. A existência em acto de uma coisa de que Aristóteles fala acima (ver citação) é, se tomada no seu aspecto estático (ou seja, como uma acção completa, terminada), a enteléquia ( $\left.\dot{c} v \varepsilon \lambda \varepsilon_{\varepsilon} \chi \varepsilon 1 \alpha\right)$ dessa coisa, a sua perfeição; pelo contrário, o acto será mais propriamente a acção de realização ou concretização que leva à actualidade. Embora a distinção entre acto e enteléquia seja por demais subtil - ao ponto de o próprio Aristóteles parecer tratar os dois termos como sinónimos -, podemos ver a enteléquia como o acto completo de uma coisa, aquilo pelo qual ela é um ente em si mesmo e no sentido absoluto. Os problemas suscitados pela distinção entre acto e potência são múltiplos e "bicudos"; por exemplo, a anterioridade no tempo (vs. anterioridade lógica) postulada por Aristóteles do acto em relação à potência (cf. Met. IX, 8), parece, à primeira vista, ir contra a nossa intuição que a matéria precede a forma. Todos estes problemas serão ampliados (e agudizados) no pensamento medieval, sobretudo na medida em que radica neste conceito aristotélico de acto a definição de Deus como o acto puro, actus purus. O capítulo 4 de $A$ Origem das Coisas Categoriais mostra bem a 2problemática desta distinção, nomeadamente no que diz respeito à passagem da potência ao acto, no pensamento escolástico.

68 Aristóteles, Met. VII, 13, 1039 a 7.

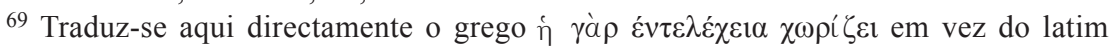
distare facit (faz diferir) por razões sintácticas. 
coisa tende à sua realização em termos de ente, assim ela tende à noção graças à qual ela difere do nada ${ }^{70}$.

(5) De modo a tornar isto claro devemos considerar que um ente tende à realização ${ }^{71}$ que lhe compete ${ }^{72}$ pelo acto e pela forma de dois modos.

(6) De um modo conforme se considera o ente com relação às suas causas, e isto no que diz respeito ao primeiro modo referido no princípio ${ }^{73}$. De um outro modo no qual se considera uma coisa com respeito à noção da sua quididade $\boldsymbol{e}$ essência absoluta, a saber, enquanto ente, e isto no que diz respeito ao segundo modo referido ${ }^{74}$.

(7) No primeiro destes modos uma coisa tende à sua realização por meio da geração. E então, como diz o Comentador em Sobre o Livro I da Física ${ }^{75}$, entre a matéria primeira e a última forma há certos intermediários ${ }^{76}$ que são como certas coisas compostas de matéria e forma e segundo os quais a matéria primeira participa cada vez mais do acto da última forma, a qual é o fim da geração, graças a uma faculdade agente. A qual participação do acto, quer se chame determinação da matéria ou essência incompleta da forma existente em potência na matéria, por ora não me interessa para nada; no entretanto uma coisa porém é certa: a matéria primeira alcança o último acto passando por diferentes graus. E estes graus são em si mesmos e próprios segundo o modo próprio e determinado da geração de cada coisa; caso contrário, seriam em vão ou por mero acaso os entes intermediários criados pela natureza no processo da geração da primeira origem de uma coisa existente em potência até ao último acto no qual termina a geração. Visto que de acordo com cada um dos intermediários que precede o último acto uma coisa é um ente em potência, eis que de acordo com nenhum deles ela é um ente de modo simples, pelo que uma tal coisa não está determinada em relação a nenhum género de ente de modo a pertencer de modo simples e em acto a um género, mas apenas de acordo com o último acto da forma graças à qual uma coisa tem a sua existência específica e realizada, pois que só por esta uma coisa é um ente em acto.

(8) Não é correcto aquilo que dizem alguns ${ }^{77}$, a saber, que de acordo com o processo da geração e da natureza certas formas precedem a última forma permanecendo simultaneamente com ela na coisa gerada de modo que de acordo com a primeira dessas formas ela é uma coisa em primeiro lugar num certo acto existindo porém em potência em relação a um acto posterior, e por aí fora até

\footnotetext{
${ }^{70}$ Mais literalmente: a noção de diferir do nada (ratio differendi a nihilo).

71 Complementum.

${ }^{72} \mathrm{Ou}$ seja, para a qual está determinado.

${ }^{73}$ Cf. 1, 2 acima.

${ }^{74}$ Cf. 1, 3 acima.

75 Averróis, In Aristotelis Phys. I, comm. 1; Venetiis, 1562, 6rE.

${ }^{76}$ Media.

77 Ex.: Guilherme de Falegar, De gradibus form.; ed. Glorieux, 297-317; Mateus de Aquasparta, Quaest. disp. de fide VI ad 10; ed. Quaracchi 1957, 159-60.
} 
à última forma, e que de acordo com estas formas essa coisa é classificada em diferentes géneros subordinados a mais geral de todos.

(9) Digo que tal não pode ser, visto que a potência e o acto são dois extremos e são como termos simples de toda a natureza ou essência que passa da potência ao acto de modo que tal como abaixo do ente em potência não se encontra mais nada pelo qual uma coisa possa permanecer num género e na natureza de ente, restando pelo contrário um puro nada, assim acima do ente em acto não se encontra nada pelo qual uma coisa estando sob esse acto possa ser formalmente criada sob um acto posterior. Falo aqui da potência que nada tem em si do acto; refiro-me aqui ao acto de acordo como o qual compete a uma coisa ser, o ultimo acto do ente enquanto ente. Assim como o acto da corrida não supõe um outro acto de correr acima de si, de modo a que esse primeiro possa realizar-se num posterior acto de correr, visto que ele é o último deste género, também o acto de ser, que ou é o mesmo que a forma de uma coisa ou convém a uma coisa em termos da forma, não supõe nenhum outro acto pelo qual uma coisa, permanecendo em acto a mesma que era antes, seja criada de acordo com um acto de ser posterior. Não se deve postular uma tal ordem e coexistência de formas, contrariamente ao que alguns afirmam.

(10) Vemos além disso em todos os géneros que a natureza do mais geral convém mais a uma coisa de acordo com a última forma, pela qual tem uma existência específica, do que de acordo com qualquer outra das formas que se supõe precederem e coexistirem simultaneamente numa mesma coisa gerada. $\mathrm{O}$ homem, bem como o cavalo, subsiste mais ${ }^{78}$ pela alma, graças à qual tem uma existência específica, do que por uma qualquer outra forma que lhe possa inerir; logo, por ela, mais do que por qualquer das outras formas, ele é uma substância. É evidente que por essa mesma última forma um homem é um homem e um cavalo é um cavalo; logo, por essa mesma última forma especifica um homem é um homem e uma substância e um cavalo é um cavalo e uma substância, o mesmo se passando em todos os outros géneros diferentes da substância. Os géneros intermediários ${ }^{79}$ de acordo com esta noção não ficam fora da ordem destes extremos, a saber, do mais geral e do mais específico, pelo facto que a natureza do mais geral não se reduz à mais específica senão pelo intermédio de naturezas subordinadas; assim, por essa mesma forma pela qual ela tem uma existência específica uma coisa inclui-se numa espécie especialíssima ${ }^{80}$, bem como num género generalíssimo ${ }^{81}$ e em todos os géneros subordinados ${ }^{82}$.

(11) Aquilo que alguns afirmam acerca da carne que resta do animal após a separação ou a corrupção da alma, a saber, que é necessário que por essa forma da carne o corpo seja o sujeito da alma, não está correcto.

\footnotetext{
78 Ou seja, tem mais subsistência.

${ }^{79}$ Media genera.

${ }^{80}$ A espécie mais específica; ex.: homem.

81 A substância.

82 Cf. a Árvore de Porfírio, Figura 1.
} 
(12) Em primeiro lugar, com efeito, porque se a carne é carne no animal vivo pela mesma forma substancial pela qual é carne após a morte do animal, segue-se que a carne do animal vivo e do morto não é carne num sentido equívoco; o que vai contra o Filósofo e o Comentador no livro VII da Metafísica ${ }^{83}$.

(13) É de igual modo evidente que a matéria e a forma no ente em si mesmo, que é uma substância, se encontram unidos não por meio de uma qualquer determinação acidental que seria formalmente o meio de união ${ }^{84}$. Com efeito, se, pela mesma forma substancial de carne em virtude da qual a carne é carne após a morte, na geração o corpo do animal fosse em potência essencial não por meio de uma determinação acidental formalmente intermediária entre o corpo e alma, mas pela sua essência naquela relação com a forma da alma a ser introduzida por um agente, então, visto que a mesma forma que a anterior se manteria, segue-se que o corpo continuaria a ter a mesma relação que tinha anteriormente com a forma; pelo que seria possível ressuscitar os animais mortos por meio de um agente aproximador ${ }^{85}$, ou melhor, será mesmo necessário que eles acabem por ressuscitar mais cedo ou mais tarde; caso contrário, uma potência que convém de alguma maneira a uma coisa de acordo com a sua espécie seria completamente em vão, algo que a natureza não permite.

(14) Também não está correcto responder que embora a forma substancial na carne após a morte possa continuar a ser a mesma que era na carne viva, não se mantém porém a mesma proporção exacta e a mesma harmonia da carne pela qual é possível ou mesmo até necessário que a alma se encontre no corpo por meio de geração.

(15) Afirmo que tal não resolve a questão. Esta harmonia graças à qual uma coisa toma existência ou perde existência substancial ${ }^{86}$ não é um acidente qualquer, nem inere formalmente de acordo com um qualquer acidente, sendo antes um certo equilíbrio de uma coisa que se considera entre os aspectos essenciais; caso contrário, um acidente seria um princípio intrínseco de uma substância e pertenceria à sua essência, o que é absurdo. Uma vez alterada a harmonia de uma coisa de acordo com a qual se considera a $<$ sua $>$ existência ou não-existência em termos de substância, é necessário alterar essa coisa nos seus aspectos essenciais; a alteração dos aspectos essenciais de uma coisa implica a alteração da essência; mas pois que a essência não permanece aquela que era anteriormente, é impossível a coisa estar sob o acto da mesma forma substancial. Logo, uma vez a harmonia da carne alterada pela morte, é necessário que a forma substancial da carne não permaneça após a morte.

${ }^{83}$ Aristóteles, Met. VII, 10, 1035b24-5; Averróis, In Aristotelis Met. VII, comm. 35, Venetiis, 1562, 187rD-F.

${ }^{84}$ Por outras palavras, na substância a matéria e a forma encontram-se formalmente ligadas por uma determinação essencial.

85 Appropinquans agens, ou seja, um agente capaz de estabelecer uma afinidade ou pertença ao mesmo género (propinquitas).

${ }^{86} \mathrm{Ou}$ seja, existência enquanto substância. 
(16) Além disso, é evidente que a harmonia a que se referem não é considerada na forma substancial da carne, a qual $<$ forma $>$ é simples. A harmonia parece ser uma proporção reservada a vários aspectos relacionados entre si. Segundo a opinião deles, esta harmonia que existe entre a forma da carne e a sua matéria própria não é alterada após a morte: mas na verdade a mesma forma da carne que ineria anteriormente já não inere na matéria, pois que não existe entre a forma e a matéria a mesma proporção que existia anteriormente; logo, de acordo com a opinião deles, convém que esta alteração da harmonia incida em certas coisas que são no sujeito formas da carne. Quer eles queiram assim que esta harmonia seja considerada nestas coisas entre os aspectos acidentais ou entre os aspectos substanciais, contanto que a alteração não seja tão grande que estas coisas não percam a proporção pela qual possam ser sujeito da forma da carne, visto que a carne em termos da sua forma substancial é em si mesma em potência e em relação à forma da alma, segue-se até agora que se se mantém a mesma forma a carne continuará a ter a mesma relação com a forma da alma, tanto porque aquilo que convém a uma coisa em si em termos da sua quididade não pode não inerir nela se ela continua a ser a mesma coisa, como porque em toda a ordem essencial das causas o segundo não se encontra sem o primeiro, como é evidente quando se trata das coisas particulares: no género das causas materiais não se encontra o elemento sem a matéria primeira, nas causas eficientes a semente não move sem uma faculdade celeste, nas causas formais o vivo não se encontra sem o ente, e por aí fora. Pelo que no que diz respeito à questão em discussão a forma da carne, pela qual ela é carne em si mesma com relação à forma da alma, não se encontra sem a alma ou sem a relação à mesma, uma vez que essa alma, embora seja a última forma no processo da geração, é porém a primeira em natureza e pela definição. Assim sendo, a alteração da harmonia no modo de que falámos em nada altera a relação da forma da carne com essa mesma alma, contanto que a forma da carne se mantenha a mesma que era antes; e assim é possível que os animais mortos ressuscitem, como se concluiu acima ${ }^{87}$.

${ }^{87}$ A forma da alma faz parte da definição do animal vivo; enquanto esta forma se mantiver no sujeito, manter-se-á a relação que ela tem inicialmente, pela via da geração, com a matéria (a carne). Se a alteração da harmonia entre a matéria e a forma causada pela morte não implica que o animal morto perca a forma da alma, então mantém-se a mesma relação que ela tinha com a matéria (a carne): assim sendo, é possível que o animal morto ressuscite. Parafraseando esta passagem complexa $(4,14-4,16)$ : no animal vivo, a carne tem a forma substancial da carne no animal vivo; tal é a determinação essencial que une a matéria e a forma no caso da carne do animal vivo. Por seu lado, no animal morto a carne tem a forma substancial da carne no animal morto, e essa é a determinação essencial que une matéria e forma neste caso. Porém, a carne do animal vivo tem a determinação acidental para se tornar carne no animal morto; no momento em que o animal morre, a determinação essencial que unia a matéria e a forma, ou seja, a carne e a alma do animal vivo, cessa; caso contrário, o animal poderia ressuscitar, pois manter-se-ia nele a determinação essencial - a forma substancial - da carne do animal vivo. Pelo menos, assim 
(17) Além disso, que a forma da carne no animal morto não é a mesma que era antes no vivo, tal mostra de modo evidente o Filósofo no livro VIII da Metafísica $^{88}$ e o Comentador no mesmo livro ${ }^{89}$, onde diz que a matéria, ao receber formas opostas, se comporta de dois modos em relação a elas. Num dos modos a matéria comporta-se em relação a formas opostas "em termos de privação"; o que de facto ocorre quando a matéria se encontra numa mesma relação com cada uma das formas e estas podem suceder-se uma à outra na mesma matéria, como quando do ar se gera o fogo e vice-versa. Este modo de recepção e de relação da matéria com as formas diz-se em termos de privação porque na matéria mais não é necessário que a privação da forma a ser recebida, e não que uma delas inira necessariamente antes de modo a que a outra possa ser recebida. Num outro modo a matéria, ao receber formas opostas, comporta-se em relação a elas "em termos de hábito"; o que é o caso quando a matéria recebe as formas segundo uma certa ordem que se considera em si entre as formas de modo a que uma delas não seja recebida a não ser que a outra se encontre na matéria de acordo com o processo e ordem da geração ou da corrupção; é assim evidente que a matéria não recebe a forma da carne a não ser que nela preceda a forma do sangue, e por aí fora.

(18) De acordo com isto, quanto a este segundo modo no processo de corrupção a matéria não recebe a forma substancial sob a qual está o ente privado a não ser que na matéria preceda o hábito ou a forma cuja privação permanece por meio de uma certa forma substancial na matéria após a corrupção do ente, como a forma do animal morto e do vinagre, os quais são entes privados numa ordem irreversível ${ }^{90}$, não inerem na matéria a não ser que nela preceda a forma do animal e a forma do vinho. A causa disto em termos de sujeito é a natureza do próprio ente que tem de ser determinado numa ordem essencial que é em $\mathrm{si}^{91}$. Falo de ordem essencial quanto à forma e à sua privação oposta na medida em que esta privação é o fim da corrupção da forma e inclui essa corrupção na sua noção, e não quanto à forma substancial do animal morto que se encontra por acidente na natureza, como se disse acima. Pelo que o Filósofo diz no livro VIII da Metafísica ${ }^{92}$ que do vivo se forma o morto não como a partir da maté-

\footnotetext{
se pode argumentar, se se considerar que a determinação potencial determina de facto, ou essencialmente, uma substância; mas segundo Teodorico tal não é o caso. Por outro lado, se se altera a forma substancial de uma coisa, característica da harmonia que a define, então inevitavelmente se altera a sua essência: a carne do animal vivo e a carne do animal morto têm formas substanciais diferentes, ou seja, são essencialmente diferentes.

${ }^{88}$ Aristóteles, Met. VIII, 5, 1044b29-34.

89 Averróis, In Aristotelis Met. VIII, comm. 14, Venetiis, 1562, 222rD-vH.

${ }^{90} \mathrm{Ou}$ seja, o animal morto não pode tornar-se vivo, nem o vinagre se pode tornar vinho.

91 Parafraseando: a matéria é o sujeito de formas diferentes (ou seja, recebe formas diferentes) que se sucedem numa ordem essencial: para que a matéria seja o sujeito do morto é necessário que antes ela tenha sido o sujeito do vivo.

92 Aristóteles, Met. VIII, 5, 1045a2-3.
} 
ria, mas sim como do dia se faz a noite, indicando assim o carácter acidental desta ordem. A causa anterior e eficiente desta ordem essencial é a duração ${ }^{93}$ determinada, própria e natural de uma coisa que de acordo com a sua sucessão natural causa esta sucessão numa ordem irreversivel; e por isso, como diz o Filósofo na mesma passagem ${ }^{94}$, não se dá o retorno do morto ao vivo nem do vinagre ao vinho a não ser que se volte à matéria primeira de cada um deles. É assim evidente que a forma da carne do animal morto nunca se encontrou na matéria antes da corrupção do animal.

(19) Daquilo que se disse segue-se que se graças a uma qualquer faculdade sobrenatural se fizesse com que num animal corrupto ${ }^{95}$ permanecesse a forma do corpo ou da carne que eles dizem que ineria antes, então esse animal não estaria realmente morto, mas dir-se-ia dele equivocamente que estava morto: não seria de facto um ente privado de acordo com as considerações anteriores. Logo, não seria um ente morto, visto que o ente privado é superior ao ente morto ${ }^{96}$ : não é suficiente para a noção de morto não ter vida de modo nenhum a não ser que seja privado de vida numa ordem irreversível. De que modo um ente privado pertence ao mesmo género ou à mesma espécie que o ente cuja privação ele implica, tal discutiu-se acima no capítulo anterior.

(20) É assim evidente de que modo uma coisa considerada em relação às suas causas no processo da geração tende ao seu acto completo graças ao qual difere do nada e <é também evidente> a falsidade da opinião acerca disto relativa à ordem e coexistência das formas ${ }^{97}$.

(21) Se porém se considerar uma coisa em termos da sua quididade e essência absoluta, a saber, enquanto ente, nesta perspectiva não se considera a ordem e a progressão em direcção à realização no processo da geração e na acção por parte de um agente natural de fazer passar da potência ao acto, mas somente em

\section{Periodus.}

94 Aristóteles, Met. VIII, 5, 1045a3-6.

95 Ou seja, morto, em decomposição.

${ }^{96}$ Note-se o modus tollens: $A \rightarrow B, \neg B \vdash \neg A$. Por extenso: (1) Se um ente é um ente morto, então esse ente é um ente privado (pois que "o ente privado é superior ao ente morto" no sentido em que a privação em causa - a privação de vida - deve ser irreversível); (2) Não é um ente privado; (3) Logo, não é um ente morto.

${ }_{97} \mathrm{Em} \mathrm{4,6}$ Teodorico informara que o ente tende à realização que lhe compete pelo acto e pela forma de modos diferentes conforme se considere o ente em relação às suas causas (cf. 1,2), ou seja, em relação à geração, ou em relação à sua quididade e essência absoluta (cf. 1, 3); de 4, 7 a 4, 19 tratou-se o primeiro destes modos, e a conclusão principal de Teodorico é que um ente é um ente completo no processo da geração em virtude do acto para o qual está determinado, acto esse que está ligado a uma forma específica, última, e de acordo com a qual uma coisa pertence a um género específico; graus intermédios ou formas, intermediárias ou possivelmente coexistentes, não alteram em nada a relação da forma última com a matéria. Estamos no âmbito da problemática, fulcral na filosofia medieval escolástica, da unidade da forma substancial: de modo a que a definição seja única, é necessário que a forma substancial seja também ela única, uma perspectiva que, como se viu, se apoia na metafísica aristotélica. 
termos da última forma de acordo com a qual uma coisa tem o acto completo numa existência específica, nomeadamente na medida em que nessa mesma e única forma se encontra a ordem em termos de diversos graus de perfeição e actualidade que convêm à forma de acordo com as como que diferentes intenções formais encontradas na forma.

(22) A noção destas intenções pode ser tomada na perspectiva seguinte: como se disse acima, em todo o género que é de facto e propriamente um género - $e$ não apenas numa perspectiva lógica ${ }^{98}$ - é necessário encontrar algo tendo a noção de matéria que seja o princípio fundamental de todo esse género e o qual se distinga de acordo com a existência diferente nos diferentes entes que pertencem a uma mesma classe em termos desse género ${ }^{99}$.

(23) Visto que esta distinção se faz por formas diferentes em acto, enquanto esse princípio material em si e na sua natureza própria tem uma única noção, $\dot{e}$ necessário que se encontre em todas as formas que o distinguem uma intenção formalmente real que tenha uma única noção correspondente à unidade desse princípio material; caso contrário não haveria entre a matéria e a forma a proporção em termos da potência e do acto que se considera neles ${ }^{100}$ em si de acordo com as suas naturezas próprias e pela qual eles pertencem a uma única classe segundo a natureza. A noção de género primeiro e supremo ${ }^{101}$ destes entes tem aqui a sua origem.

(24) Então, visto que o uno e o mesmo em nada essencialmente se distingue e separa nos diferentes entes em realidade e pela razão a não ser que primeiro a sua natureza pertença a essa classe que se considera segundo a primeira oposição, pela qual em primeiro lugar os entes se distinguem uns em relação aos outros - isto é a afirmação e a negação no sujeito, a qual nada mais é que a forma e a privação, a primeira contrariedade em qualquer género que seja, como diz o Filósofo ${ }^{102}$-, pois que esta contrariedade se funda por essência nos entes a sua noção deverá ter apenas dois extremos, dos quais cada um tem uma única noção, pelo que nos entes que se classificam sob um ou outro destes extremos é igualmente necessário encontrar uma intenção formal pela qual tenham uma única noção, uns de acordo com um dos extremos, outros de acordo com o outro. O que faz com que pertençam a uma única classe em termos de um género subordinado; e assim se prossegue por ordem até à última forma do acto específico de acordo com a qual se considera a noção da espécie especialíssima.

(25) De acordo com isto, num único e mesmo acto ou forma específica radicam as intenções de todos os géneros superiores e da espécie especialissima no modo referido. Estes géneros e espécies não são com efeito formas realmente

$98 \mathrm{Ou}$ seja, um género é de facto e propriamente um género somente numa perspectiva metafísica (cf. 3, 11 e 3,12 acima para as perspectivas respectivamente metafísica e lógica).

${ }^{99}$ Cf. 3, 11 acima.

100 Entes.

101 Por oposição a género intermédio ou subalterno.

102 Aristóteles, Met. X, 4, 1055a33. 
diferentes, nem se obtêm a partir de formas realmente diferentes, mas sim a partir da mesma forma de acordo com as diferentes intenções dessa forma em sucessão pela ordem dos seus ${ }^{103}$ diferentes graus de perfeição e actualidade. Não de tal modo que uma coisa possa ser em termos de um qualquer acto de ser em si mesma de acordo com um destes graus até ao último sem aquele que é o último grau dessa ordem: seria então possível encontrar algo existente na natureza de acordo com a forma de género e não tendo nenhum acto específico, o que é impossível ${ }^{104}$. Consideram-se estes diferentes graus de perfeição de acordo com a progressão em direcção à realização última ${ }^{105}$ do acto específico, a partir do qual se considera a diferença específica e, logo, a noção da espécie especialíssima; pelo que os actos, bem como as perfeições que os géneros superiores indicam, mais não são que certas participações da última forma e da actualidade completa da forma específica. Daqui se segue que, porque uma coisa não tem um acto de ser senão de acordo com aquele que é o seu último acto por essência, nada se encontra num género que não se encontre numa sua espécie especialíssima.

(26) Aquilo que se disse, <a saber,> que estes géneros assim classificados hierarquicamente nem são formas realmente diferentes nem são estabelecidos por formas realmente diferentes, é, para além das considerações acima, igualmente evidente pelo que se dirá a seguir.

(27) É evidente que estas formas - que alguns dizem porque simples - são completamente diferentes e cada uma delas está completamente fora de outra qualquer; logo, a partir delas não se faz um ente senão por adiçã $\boldsymbol{o}^{106}$. Segue-se pois que uma espécie ou uma coisa tendo um acto de ser específico não é um ente único a não ser por adição e que a definição que une em si estas formas não é única senão por adição; o que vai contra o Filósofo ${ }^{107}$ e o Comentador ${ }^{108}$ no livro VII da Metafísica, onde se mostra que se o género fosse dividido entre alguns entes que não fazem parte da natureza de um género, então a definição não seria única, assim como aquilo que é uma superfície branca não é em si mesmo uno graças à unidade que é a unidade da definição, como o é o animal racional. Com efeito, o branco não faz parte da natureza e da quididade da superfície, mas o racional faz parte da natureza do animal; pelo que o Filósofo diz no livro VII da Metafísica ${ }^{109}$ : "A essência da superfície não é a essência da brancura"; e o Comentador diz na mesma passagem 110: "Quando dizemos 'a superfície branca', a brancura não é a quididade da superfície como a racionalidade é a quididade do animal quando dizemos 'o animal racional"'.

103 Das intenções.

104 Parafraseando: uma coisa é em si mesma em acto somente de acordo com o último grau de perfeição e actualidade, isto é, de acordo com $o$ seu acto específico.

105 Ultimum complementum.

106 Per aggregationem.

107 Aristóteles, Met. VII, 4, 1029b13-22.

108 Averróis, In Aristotelis Met. VII, comm. 11, Venetiis 1562, 161vI-162rA.

109 Aristóteles, Met. VII, 4, 1029b17-18.

110 Averróis, In Aristotelis Met. VII, comm. 11, Venetiis 1562, 161vI-K. 
(28) Não é adequado aquilo que alguns respondem a estas considerações, a saber, que os entes que são diferentes de modo simples, dos quais cada um é ente em acto completo, não fazem um ente senão por adição, mas que isto não se aplica a estas formas dos géneros, relacionadas umas com as outras em termos da potência e do acto, das quais se forma um ente em si mesmo.

(29) Afirmo que isto não é correcto. Em primeiro lugar porque esta opinião vai contra a posição deles. Dizem com efeito que uma coisa não só anteriormente em natureza mas também no tempo de acordo com o processo da geração primeiro está sob uma forma mais geral, depois sob uma forma menos geral que permanece simultaneamente com a primeira, e por aí fora até à última, a forma específica; e assim as formas mais gerais não têm a noção da potência, sendo antes um certo acto.

(30) Em relação ao que se seguem absurdos. Visto que cada uma delas dá o acto de ser, que nos entes essenciais ${ }^{111}$ é simplesmente o último acto na natureza, cada uma delas será simplesmente o último acto na natureza e, logo, o acto completo, não tendo pois uma relação em termos de potência com um acto posterior. Segue-se logo que ou existirão numa mesma coisa muitos actos de ser, e assim uma mesma coisa será múltipla em número, visto que as coisas se enumeram ${ }^{112}$ pelo acto de ser, ou a partir de todos os actos se produzirá um único ente e assim a partir de muitos entes em acto existirá um único ente juntamente com aquilo que será um princípio formal contendo-os $\langle$ todos $\rangle$, o que é impossível, como mostra o Filósofo no fim do livro VII da Metafísica ${ }^{113}$, visto que cada um deles seria o último e o mais formal na natureza, ao qual não se pode formalmente fazer uma adição; ou todos os actos precedentes excepto o último serão destruídos e então as formas de acordo com as quais os actos têm de convir serão de igual modo destruídas - e temos então a questão principal, a saber, que não há senão uma única e última forma numa coisa gerada - ou, se se mantêm as formas sem estes actos de ser, segue-se que algo permaneceria sem aquilo que inere nele essencialmente ${ }^{114}$ : o que é impossivel, como se pudesse haver um quaternário sem paridade ${ }^{115}$ e um senário sem perfeição ${ }^{116}$.

(31) Além disso, dizer que estas formas têm essa relação umas com as outras que eles dizem que elas têm não contorna a posição de Aristóteles. Seja qual for o modo segundo o qual elas se relacionam <umas com as outras $>$, qualquer uma delas estará contudo fora da natureza de qualquer uma delas: o que a natureza e a unidade da definição não permitem, como se disse. É assim evidente a partir disto que segundo o Filósofo a unidade da definição não é considerada na unidade da relação que é a da potência e do acto que se considera entre a matéria e a forma ou entre o que quer que seja que possua uma composição mútua; a unidade da

111 Ou seja, os entes que são em si mesmos.

112 Se individuam.

113 Aristóteles, Met. VII, 17, 1041b11-33.

114 Ou seja, a forma existiria sem o acto de ser que lhe é inerente de modo essencial na medida em que a forma é o que dá o acto de ser.

115 Boécio, Inst. arithm. I, 9; ed. Friedlein, 17-18.

116 Ibid., 19; ed. Friedlein, 41. 
definição radica antes na unidade da forma ou do acto específico. $\mathrm{O}$ que é assim evidente. De facto, segundo o Filósofo no livro IV da Metafisica ${ }^{117}$, a noção que o nome significa é a definição. O nome da espécie é dado pela forma específica; logo, as partes da forma que são explicadas na definição não são senão partes de uma única forma específica. Pois que estas partes não são senão formas e naturezas dos géneros superiores e das diferenças, é evidente que todos estes não são com efeito senão uma única forma específica. E isto é o que o Filósofo diz ${ }^{118}$, a saber, que a noção da unidade da definição vem integralmente da unidade da última diferença: todas as formas dos géneros e das diferenças superiores não são senão uma certa formalidade partilhada da última diferença, da qual vem integralmente a entidade e a unidade da espécie enquanto tal, como da forma substancial vem integralmente a entidade e a unidade do ente segundo a natureza.

(32) É pois evidente que as formas dos géneros organizados de modo hierárquico não são formas de facto diferentes nem são estabelecidas a partir de formas de facto diferentes, mas são-no, como se disse, a partir de uma mesma forma de acordo com as diversas intenções dessa mesma forma; as quais contudo não se relacionam umas com as outras no que respeita àquilo que são de modo que uma se encontre fora da natureza da outra e que deste modo uma se forme a partir delas por adição, como se disse acerca das formas. Nem se salvaguardaria assim a unidade de uma coisa de acordo com a natureza, faltando essa unidade que é de acordo com a forma, nem seria única a definição na qual é necessário que tudo seja uno na unidade do último formal que é a última diferença.

(33) Assim, estas intenções formais relacionam-se umas com as outras não de acordo com a relação da potência e do acto, a menos que falemos de potência e de acto num sentido menos próprio e mais lato. Deste modo, ou seja, de acordo com a relação da potência e do acto, existem quanto aos aspectos substanciais de uma coisa diferentes graus da sua essência segundo o progresso para o acto completo no processo da geração. Cada uma dessas intenções importa o acto da coisa; pelo que as formas dos géneros, das diferenças e das espécies, que no modo mencionado têm a sua origem a partir dessas intenções, são predicadas de uma coisa existindo em acto: de facto, frequentemente não se encontram as ditas intenções numa coisa senão no fim da geração, a qual termina no acto específico de uma coisa na natureza. Pelo que elas são como certos princípios formais de uma única forma completa, dos quais porém cada um importa integralmente $o$ acto da forma, embora de modos diferentes, de forma que umas de maneira menos determinada, outras de facto de maneira mais determinada, como se pode ver na organização hierárquica dos géneros que se obtém originalmente a partir delas, dos quais cada um importa integralmente o acto específico, embora de modo menos determinado, e neste mesmo acto se encontra a diferença entre os géneros. Só a espécie assim importa de modo determinado o acto específico, de modo que o posterior não é determinável por algo formal, como o ente de modo simples. Estas intenções relacionam-se assim umas com as outras pela ordem do

${ }^{117}$ Aristóteles, Met. IV, 7, 1012a23-24.

118 Aristóteles, Met. VII, 12, 1038a19-20. 
indeterminado ou menos determinado para o determinado ou mais determinado numa única e mesma forma. Mais precisamente, quanto àquilo que são, não são senão uma mesma forma, diferentes apenas pela razão, pela razão, digo, não na maneira daquela que é uma coisa de intenção segunda, mas tal como a noção na natureza a intenção de uma coisa é aceite ${ }^{119}$.

(34) Logo, de acordo com as considerações acima aquilo que quanto ao modo de formar-se ${ }^{120}$ se considera numa coisa quanto ao processo da geração é de certo modo semelhante no que respeita ao modo de ser na questão em discussão. Com efeito, assim como numa coisa que progride para o acto completo no processo da geração a matéria participa gradualmente ${ }^{121}$ cada vez mais da perfeição do acto último e completo, como se disse acima, porém de modo que do acto e da potência não se forme uma composição, mas que da potência se forme o acto, assim, digo, se passa semelhantemente numa coisa segundo o último acto de ser, nomeadamente que numa mesma coisa de acordo com uma única última forma se encontram diferentes graus de perfeição e actualidade segundo os quais se obtêm diferentes géneros organizados hierarquicamente, mas de modo que nem destes graus de distintas perfeições entre si nem de igual modo dos mesmos géneros entre si se forme uma composição real, mas antes um ente se torne noutro, nomeadamente que do indeterminado $<$ se forme $>$ o determinado e que do menos determinado $<$ se forme $>$ o mais determinado ${ }^{122}$ de acordo com a progressão para a perfeição última e completa do acto específico ${ }^{123}$.

119 O que Teodorico nos diz neste parágrafo é que embora as intenções formais de uma coisa se relacionem umas com as outras, aparentemente - e num sentido muito lato e menos próprio - em termos da relação da potência e do acto, na medida em que vão do indeterminado ou menos determinado para o determinado ou mais determinado, só a espécie importa de facto o acto específico de acordo com o qual o ente é e é aquilo que é. Assim sendo, estas intenções são de facto apenas uma única e mesma forma, só sendo diferentes pela razão, mas não no sentido em que a razão supostamente cria apenas coisas de intenção segunda; pelo contrário, a espécie é de facto um ente real. Teodorico está aqui a dar um passo importante para a fundamentação da sua tese que toda a realidade é um fruto do intelecto: as espécies e os géneros são também entes reais (naturais), embora criados pelo intelecto, não sendo meras coisas de razão ou coisas de intenção segunda: pelo contrário, é graças a eles que se pode falar de um acto específico de um ente enquanto ente, acto sem o qual só resta o não-ente. A conclusão é radical: a natureza é uma criação do intelecto. No quinto capítulo a justificação é engenhosa: o intelecto é anterior à natureza, pelo que esta é uma criação do intelecto.

${ }^{120}$ Modus fiendi; tome-se aqui, bem como ao longo deste parágrafo, formar-se num sentido sobretudo passivo ("se" apassivante). Para além disso, tenha-se em mente o facto que formar implica acima de tudo a presença de uma forma. Tome-se ainda formar-se como sinónimo de tornar-se.

121 Mais literalmente: de acordo com diferentes graus.

$122 \mathrm{Ou}$ que o indeterminado se torne determinado e o menos determinado se torne mais determinado.

${ }^{123}$ Note-se a subtileza desta comparação: Teodorico compara o acto natural e o acto do intelecto, mostrando que ambos resultam num ente único e uno. 
(35) Mas deparamo-nos aqui com um problema: se nestes entes de que se falou se passa que no processo da geração um ente se forma a partir de outro ou um ente se torna noutro, não de maneira que haja uma modificação na essência ou uma adição na essência, como diz o Filósofo no livro VIII ${ }^{124}$, mas $<$ de modo que> a mesma essência é daquilo que é o ente em potência e daquilo que é o ente em acto, embora de acordo com diferentes graus de potência e de acto; visto que pois entes diferentes em acto, como a carne do cavalo e a carne do boi, podem formar-se a partir de uma e mesma coisa que é em potência qualquer um deles, como por exemplo a partir do alimento ${ }^{125}$, segue-se um dos três casos seguintes: em primeiro lugar, se a potência é una a partir da qual se produzem estes diferentes entes, então eles não serão diferentes, visto que duas coisas que são iguais em relação a uma e mesma coisa são iguais entre si ${ }^{126}$. Mas cada um destes entes é igual com relação à potência por essência de acordo com o que se disse: logo, eles serão iguais entre si. Ou então segue-se um outro caso, a saber, que numa e mesma coisa, por exemplo no alimento, estas potências são diferentes. Mas isto vai contra o Filósofo no livro VII da Metafísica ${ }^{127}$, onde diz que só o acto separa ${ }^{128}$.

(36) Além disso, não parece ser concebível que diferentes entes formalmente distintos existam num mesmo ente de acordo com o mesmo e contudo não formem uma mistura; esta potência não será em si mesma distinta e diferente. Se estes casos são absurdidades, segue-se um terceiro, a saber, que a essência existente em potência e a existente em acto a partir da potência não é a mesma, o que vai contra as considerações anteriores.

(37) Pode-se de igual modo objectar no que diz respeito ao género e às espécies a ele subordinadas.

(38) Mas temos de ter em mente que os entes que pertencem a um ente de acordo com a noção de ente se proporcionam ao ente e seguem o seu modo segundo a noção do existente ou do não-existente. De igual modo no que diz respeito à noção da potência e do acto: os entes que convêm a um ente de acordo com a sua ${ }^{129}$ própria noção não podem existir ou ser em acto se esse ente não existe ou se ele é apenas em potência. Logo, nestes entes, embora possam ser de modo simples ou que de acordo com eles se considere uma qualquer comparação entre os entes, esse mesmo ente é necessário. Ora como o mesmo e o diferente pertencem ao género daqueles entes que pertencem a um ente enquanto ente, comparam-se incorrectamente alguns entes uns com os outros como sendo iguais ou simplesmente diferentes, a menos que estes entes sejam entes de modo simples, o que significa a existência em acto. Pelo que, onde se terá feito uma

124 Aristóteles, Met. VIII, 6, 1045a23-33.

${ }^{125} \mathrm{Ou}$ seja, o alimento (panis) é em potência indiferentemente a carne quer do cavalo quer do boi.

126 Cf. Euclides, Elem. I, comm. a. conc. 1; ed. Heiberg-Stamatis, 5.

${ }^{127}$ Aristóteles, Met. VII, 13, 1039a7.

128 Ver acima.

129 Do ente. 
tal comparação, tais expressões devem ser substituídas por outras de termos absolutos $^{130}$.

(39) Assim, quando se pergunta se o ente em potência e o ente em acto são o mesmo nos entes que passam da potência ao acto, nesta questão não se pressupõe o ente nem se faz uma comparação de um ente de modo simples com um ente de modo simples, fazendo-se pelo contrário uma comparação entre a essência por assim dizer do mesmo ente consigo próprio de acordo com os seus diferentes graus em termos da potência e do acto, a partir do qual ele tem de ser analisado. É o mesmo que perguntar se do ente em potência se forma um ente em acto de tal modo que deles se forma um certo composto, ou de tal modo que a potência se torna acto. O Filósofo postula estes dois modos no livro IX da Metafísica ${ }^{131}$, onde diz que a potência e o acto relacionam-se entre si de dois modos. Num modo como nisto ${ }^{132}$, a saber, para que a forma seja na matéria, e isto no que respeita ao primeiro modo; num outro modo como para isto ${ }^{133}$, como o movimento é no que diz respeito à potência ${ }^{134} \mathrm{e}$ a forma em acto no que diz respeito à forma em potência ${ }^{135}$, e isto no respeitante ao segundo modo. De acordo com aquele modo afirmou-se que não se forma um composto da potência e do acto; e de acordo com este modo deve-se dizer que a essência do ente em potência e do ente em acto é a mesma, seja segundo a passagem de uma coisa da potência ao acto no processo da geração, seja segundo a organização hierárquica dos géneros. E esta potência tomada em si mesma e de modo absoluto é una por causa da privação ou da ausência de actos distintos, como Averróis diz acerca da unidade da matéria primeira ${ }^{136}$, como os raciocínios anteriores concluíam, mas capta contudo a noção da diversidade em relação aos diferentes actos. E então não se segue o absurdo que se inferia deste princípio: quaisquer entes que são iguais em relação a uma e mesma coisa etc. ${ }^{137}$ Agora a potência em relação aos diferentes actos já não é uma e a mesma, como se disse.

(40) Além disso, esta proposição compreende-se por si própria e é própria nestes casos em que em todos os três termos entre os quais se faz uma comparação há o ente num modo simples e o ente de uma única noção; o que não se

${ }^{130}$ Parafraseando as últimas linhas deste parágrafo: só se podem fazer comparações entre termos absolutos, o que no caso de entes implica que só entes completos ou em si mesmos podem ser termos de comparação.

131 Aristóteles, Met. IX, 6, 1048b6-9.

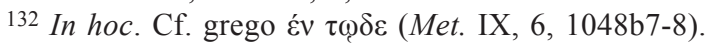

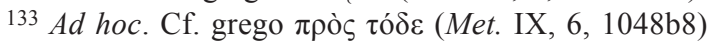

134 O movimento é a passagem da potência ao acto (cf. Aristóteles, Phys. III, 1, 201a),

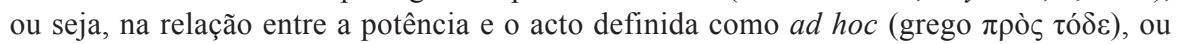
de um termo inicial ( $\varepsilon_{\xi} \xi$ oṽ) para um termo final (Eiç ó), o movimento é a potência em acto (ou a actualização da potência) (cf. Aristóteles, Met. XI, 9, 1065b16).

135 A forma em potência existe com vista a uma forma em acto.

136 Averróis, In Aristotelis Met. XII, comm. 11; Venetiis, 1562, 297rD-E; In Aristotelis Phys. I, comm. 63; Venetiis 1562, 38rB-D.

${ }^{137}$ Euclides, Elem. I, comm. a. conc. 1; ed. Heiberg-Stamatis, 5. 
encontra na questão em discussão, como é evidente se se examinar atentamente a questão.

(41) Assim se mostram dois modos segundo os quais se vê que os entes tendem para a realização ${ }^{138}$ que lhes compete e de acordo com o qual têm existência em termos do acto específico, e consequentemente aquilo que era a questão principal torna-se evidente, a saber, que o ente em si mesmo de modo simples e em primeiro lugar difere do nada pelo facto de ter um acto completo.

138 Complementum. 